Article

\title{
Enantioselectivity of Chiral Derivatives of Xanthones in Virulence Effects of Resistant Bacteria
}

\author{
Fernando Durães ${ }^{1,2}$, Sara Cravo ${ }^{1,2} \mathbb{D}$, Joana Freitas-Silva ${ }^{2,3} \mathbb{D}$, Nikoletta Szemerédi ${ }^{4} \mathbb{D}$, \\ Paulo Martins-da-Costa $2,3\left(\mathbb{D}\right.$, Eugénia Pinto ${ }^{2,5} \mathbb{D}$, Maria Elizabeth Tiritan ${ }^{1,2,6} \mathbb{D}$, Gabriella Spengler $4(\mathbb{D}$, \\ Carla Fernandes $1,2, * \mathbb{D}$, Emília Sousa ${ }^{1,2, * \mathbb{D}}$ and Madalena Pinto ${ }^{1,2} \mathbb{D}$
}

check for updates

Citation: Durães, F.; Cravo, S.; Freitas-Silva, J.; Szemerédi, N.; Martins-da-Costa, P.; Pinto, E.; Tiritan, M.E.; Spengler, G.; Fernandes, C.; Sousa, E.; et al. Enantioselectivity of Chiral Derivatives of Xanthones in Virulence Effects of Resistant Bacteria. Pharmaceuticals 2021, 14, 1141. https://doi.org/10.3390/ph14111141

Academic Editor: Donatella Tondi

Received: 20 October 2021

Accepted: 9 November 2021

Published: 10 November 2021

Publisher's Note: MDPI stays neutral with regard to jurisdictional claims in published maps and institutional affiliations.

Copyright: (c) 2021 by the authors Licensee MDPI, Basel, Switzerland. This article is an open access article distributed under the terms and conditions of the Creative Commons Attribution (CC BY) license (https:// creativecommons.org/licenses/by/ $4.0 /)$.
1 Laboratory of Organic and Pharmaceutical Chemistry, Department of Chemical Sciences, Faculty of Pharmacy, University of Porto, Rua de Jorge Viterbo Ferreira, 228, 4050-313 Porto, Portugal; fduraes5@gmail.com (F.D.); scravo@ff.up.pt (S.C.); elizabeth.tiritan@iucs.cespu.pt (M.E.T.); madalena@ff.up.pt (M.P.)

2 CIIMAR - Interdisciplinary Centre of Marine and Environmental Research, University of Porto, Novo Edifício do Terminal de Cruzeiros do Porto de Leixões, Avenida General Norton de Matos, S/N, 4450-208 Matosinhos, Portugal; joanafreitasdasilva@gmail.com (J.F.-S.); pmcosta@icbas.up.pt (P.M.-d.-C.); epinto@ff.up.pt (E.P.)

3 ICBAS-Institute of Biomedical Sciences Abel Salazar, Universidade do Porto, Rua de Jorge Viterbo Ferreira, 228, 4050-313 Porto, Portugal

4 Department of Medical Microbiology, Albert Szent-Györgyi Health Center and Albert Szent-Györgyi Medical School, University of Szeged, Semmelweis utca 6, 6725 Szeged, Hungary; szemeredi.nikoletta@med.u-szeged.hu (N.S.); spengler.gabriella@med.u-szeged.hu (G.S.)

5 Laboratory of Microbiology, Department of Biological Sciences, Faculty of Pharmacy, University of Porto, Rua de Jorge Viterbo Ferreira, 228, 4050-313 Porto, Portugal

6 CESPU, Institute of Research and Advanced Training in Health Sciences and Technologies (IINFACTS), Rua Central de Gandra, 1317, 4585-116 Gandra, Portugal

* Correspondence: cfernandes@ff.up.pt (C.F.); esousa@ff.up.pt (E.S.)

Abstract: Antimicrobial peptides are one of the lines of defense produced by several hosts in response to bacterial infections. Inspired by them and recent discoveries of xanthones as bacterial efflux pump inhibitors, chiral amides with a xanthone scaffold were planned to be potential antimicrobial adjuvants. The chiral derivatives of xanthones were obtained by peptide coupling reactions between suitable xanthones with enantiomerically pure building blocks, yielding derivatives with high enantiomeric purity. Among 18 compounds investigated for their antimicrobial activity against reference strains of bacteria and fungi, antibacterial activity for the tested strains was not found. Selected compounds were also evaluated for their potential to inhibit bacterial efflux pumps. Compound $(R, R)-8$ inhibited efflux pumps in the Gram-positive model tested and three compounds, $(S, S)-8$, $(R)-17$ and $(R, S)-18$, displayed the same activity in the Gram-negative strain used. Studies were performed on the inhibition of biofilm formation and quorum-sensing, to which the enantiomeric pair $\mathbf{8}$ displayed activity for the latter. To gain a better understanding of how the active compounds bind to the efflux pumps, docking studies were performed. Hit compounds were proposed for each activity, and it was shown that enantioselectivity was noticeable and must be considered, as enantiomers displayed differences in activity.

Keywords: xanthones; chiral; antibacterial; efflux pumps; biofilm; quorum-sensing; enantioselectivity

\section{Introduction}

Antimicrobial peptides are proteins produced by several hosts as a defense mechanism against bacteria. They are a response from the innate immune system, and to this day, still present effectiveness against a multiplicity of pathogenic microbes [1,2]. They are composed of amino acids and, therefore, present an amphipathic character, and their cationic charge is able to latch onto the negatively charged bacterial membrane, where they can insert and originate pores, which can ultimately lead to bacterial death [3]. However, several other mechanisms have been brought to light, such as competition with magnesium 
and calcium ions, bound to lipopolysaccharides in the outer membrane of Gram-negative bacteria, which will lead to membrane destabilization, and, therefore, the entrance of peptides, having a bactericidal effect, either through the leakage of internal organelles or through interaction with internal substances [4].

Since these compounds possess an exposed cationic part and a hydrophobic core, they can establish an initial electrostatic interaction, allowing them to adsorb and aggregate in the negatively charged part of the membrane and also to insert into the membrane due to their hydrophobic moiety [3,4]. These compounds have proven to be effective in both Gram-positive and Gram-negative bacteria [5-9]. In Gram-negative bacteria, they must permeabilize the outer membrane before reaching the cytoplasmic membrane, whereas in Gram-positive they can diffuse through small pores in the peptidoglycan layer [10]. Even though the mechanism of action of these peptides is not fully understood [11], it is known that they can act via membrane disruption and immunomodulation [2]. For instance, in Gram-positive bacteria, antimicrobial peptides can interact with lipoteichoic acid in the cell wall, which by its turn leads to the activation of autolysins, ultimately resulting in bacterial death [12].

Antimicrobial peptides have also been shown to display effective activity against other resistance mechanisms, such as biofilm [13,14] and quorum-sensing, a communication mechanism that modulates the virulence of bacteria [15]. Interestingly, peptides are also chemical signals used for Gram-positive bacteria to communicate via quorum-sensing, which can be used not only for intra-species communication but also with the host [16].

Despite their usefulness, and since these peptides are part of a ubiquitous defense system for eukaryotic organisms, resistance to these compounds has already arisen $[17,18]$, manifesting through multiple mechanisms: electrostatic repulsion of the peptides and modification in the composition of the membrane, repelling the compound and preventing its entrance, respectively $[19,20]$; peptide degradation or inhibition by proteases and other proteins [21,22]; capsule shedding, a phenomenon triggered by antimicrobial peptides that consist on trapping the peptide within a polysaccharide capsule, thus shielding the bacteria [23]; they can also modulate genes related to resistance [24,25]; and overexpression of efflux pumps, responsible for the increased efflux of antimicrobials from bacteria [26,27].

As such, strategies are being developed to obtain peptide-like molecules with lower manufacturing costs, higher stability, and able to retain activity in the presence of salts. The development of small molecule peptidomimetics has become an attractive field in this sense, and one example is the synthesis of amino acid substituted xanthones. In fact, the substitution of the hydrophobic xanthone core with cationic peptide moieties has shown promising results for the development of new antibacterial agents [28,29]. Our group has already described xanthones as antimicrobials in susceptible and resistant strains [30,31], and very recently as inhibitors of antimicrobial resistance mechanisms [32]. Moreover, enantioselectivity studies associated with the biological activity of chiral derivatives of xanthones and thioxanthones were also performed by our group [33-37]. Actually, for some chiral derivatives, enantioselectivity was found in tumor cell growth inhibition [33,34,37], cyclooxygenases inhibition [36], and P-glycoprotein (P-gp) induction [35].

Regarding antimicrobial activity, it is important to highlight that the configuration of the stereogenic centers is often ignored, and only a few examples describe the activity for both enantiomers [38,39]. Nevertheless, differences in the antimicrobial activity between enantiomers or epimers have been observed. One example concerns the naturally occurring epimers of scortechinone A and L, being scortechinone L more active against bacteria [40].

Herein, new molecular modifications to the xanthone scaffold were planned in order to synthesize chiral peptide-like derivatives and investigate their antimicrobial activity, as well as mechanisms of antibacterial resistance, specifically inhibition of efflux pumps, biofilm formation, and quorum-sensing. The synergy of these compounds with a $\beta$ lactam antibiotic in a resistant strain of a clinically relevant bacterial species was also studied. Docking studies were performed to gain a better understanding of how these compounds could interact with relevant bacterial efflux pumps. For each chiral peptide-like 
derivative, both enantiomers were synthetized, in high enantiomeric purity, to explore enantioselectivity in all assays. The results obtained show the potential of these compounds acting in different mechanisms, suggesting these chiral peptide-like xanthones could be useful in tackling antimicrobial resistance.

\section{Results and Discussion}

\subsection{Chemistry}

A library of 18 xanthone derivatives with different substitution patterns in one ring (3,4-substituted) or both rings (2,6-substituted) of the benzopyrano scaffold was synthesized, starting from hydroxy-(Scheme 1) or carboxy-xanthone (Scheme 2) building blocks.

The synthesis of the methoxylated xanthone 1 has also been previously described, through a benzophenone intermediate, which produced the main product 3-methoxy-4hydroxy-9H-xanthen-9-one (2), but also the secondary products 3,4-dihydroxy-9H-xanthen9-one (3) and 3-hydroxy-4-methoxy-9H-xanthen-9-one (4), which were used for the synthesis of derivatives [41]. Amines and amino alcohols were chosen as chiral building blocks, to demonstrate the efficiency and applicability of this methodology, resulting in a peptide bond. Activation of a carboxyl group for the formation of peptide bonds can be achieved by in situ activation using coupling reagents [42].

First, a direct coupling reaction to the phenol of compound 2 with a chiral building block using (1-cyano-2-ethoxy-2-oxoethylidenaminooxy) dimethylamino-morpholinocarbenium hexafluorophosphate (COMU) was attempted, although many secondary products were obtained, demonstrating to be an inefficient process. The same reaction was also attempted with 2-(1H-benzotriazole-1-yl)-1,1,3,3-tetramethyluronium tetrafluoroborate (TBTU), but the results were also not satisfactory. In order to accomplish this coupling with chiral building blocks, a short spacer was introduced through a Williamson ether synthesis with methyl 2-bromoacetate affording compound 9. After an alkaline hydrolysis of the ester (10), coupling reactions with suitable chiral building blocks were performed, using TBTU, affording the desired products (both enantiomers of 11).

Coupling reactions were carried out in anhydrous conditions in order to prevent hydrolytical degradation and the formation of secondary products [43]. These reactions occurred at room temperature with 2 equivalents of triethylamine (TEA) and a slight equivalent excess of coupling reagent and chiral building block (1.1 equivalent). These reactions were carried out with both enantiomers of enantiomerically pure commercial building blocks with no tendency towards racemization or enantiomeric interconversion. The building blocks $(R)-(-)$ and $(S)-(+)-2$-phenylglycinol, and $(R)-(+)$ and $(S)-(-)-(\alpha)-$ methylbenzylamine have a primary amine as a reactive group for amide synthesis. Purification processes involved chemical extractions and filtration steps, flash chromatography, and crystallization.

The synthetic pathways used for the syntheses of compounds 6-12 are displayed in Scheme 1.

The synthesis of xanthones 13,14 , and the enantiomeric pair 15 was previously described [37,44]. Then, to couple an additional chiral moiety in the C6 position, a demethylation step took place, followed by a Williamson ether synthesis with methyl bromoacetate (16). In order to perform the coupling with the chiral building blocks, the ester was hydrolyzed to a carboxylic acid (17), thus allowing the coupling using TBTU to afford the final compounds 18. Scheme 2 shows the syntheses leading to 2,6-substituted chiral derivatives of xanthones 16-18. 


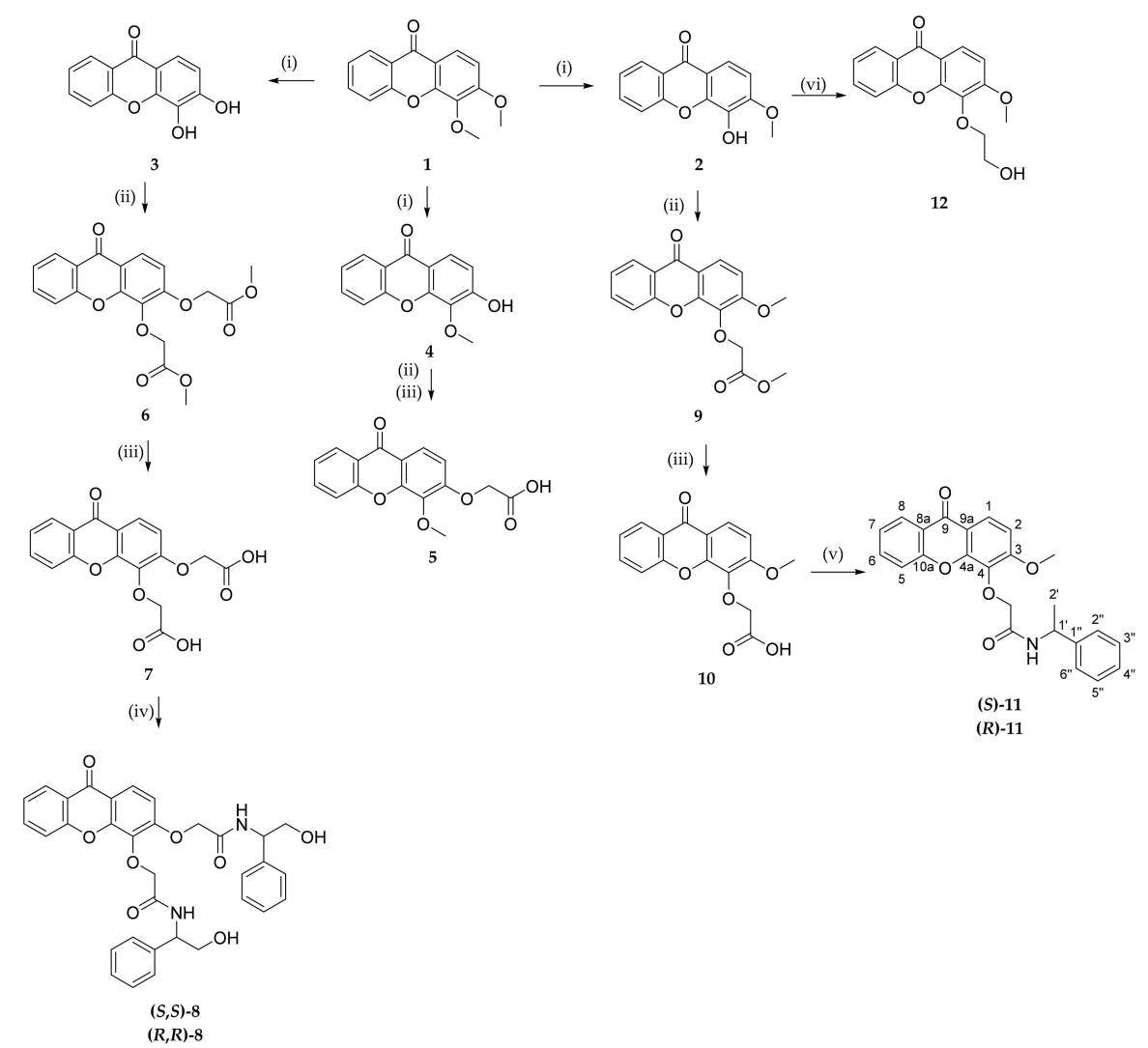

Scheme 1. Synthetic pathways for obtaining 3,4-substituted chiral derivatives of xanthones used in this study. (i) $\mathrm{AlCl}_{3}$, anhydrous toluene, $70{ }^{\circ} \mathrm{C}$, $40 \mathrm{~min}$; (ii) $\mathrm{BrCH}_{2} \mathrm{COOCH}_{3}, \mathrm{~K}_{2} \mathrm{CO}_{3}$, anhydrous acetone, 4-24 h; (iii) $\mathrm{NaOH} 5 \mathrm{M}, \mathrm{CH}_{2} \mathrm{Cl}_{2}: \mathrm{CH}_{3} \mathrm{OH}$ $(1: 1 \mathrm{v} / \mathrm{v}), \mathrm{rt}, 5-24 \mathrm{~h}$; (iv) (R)-(-) or (S)-(+)-2-phenylglycinol, TBTU, anhydrous THF, TEA, rt, $5 \mathrm{~h} ;(\mathrm{v})(R)-(+)$ or $(S)-(-)-(\alpha)-$ methylbenzylamine, TBTU, TEA, anhydrous THF, $2 \mathrm{~h}$; (vi) $\mathrm{BrCH}_{2} \mathrm{CH}_{2} \mathrm{OH}, \mathrm{NaH}$, anhydrous acetone, reflux, $14 \mathrm{~h}$.

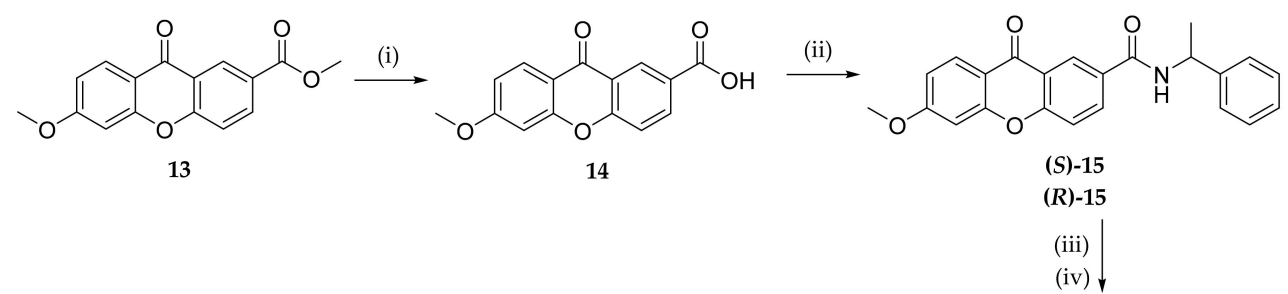<smiles>CC(NC(=O)c1ccc2oc3cc(OCC(=O)O)ccc3c(=O)c2c1)c1ccccc1</smiles>

(S)-17

(R)-17

(v)<smiles>O=C(COc1ccc2c(=O)c3cc(C(=O)Nc4ccccc4)ccc3oc2c1)NC(CO)c1ccccc1</smiles><smiles>COC(=O)COc1ccc2c(=O)c3cc(C(=O)NC(C)c4ccccc4)ccc3oc2c1</smiles>

Scheme 2. Synthetic pathways for obtaining 2,6-substituted chiral derivatives of xanthones used in this study. (i) $\mathrm{NaOH}$ $5 \mathrm{M}, \mathrm{CH}_{2} \mathrm{Cl}_{2}: \mathrm{CH}_{3} \mathrm{OH}(1: 1 \mathrm{v} / \mathrm{v})$, rt, 5-22 h; (ii) (R)-(+) or (S)-(-)-( $\left.\alpha\right)$-methylbenzylamine, TBTU, anhydrous THF, TEA, rt, $1 \mathrm{~h}$; (iii) $\mathrm{Et}_{2} \mathrm{NCH}_{2} \mathrm{SH} . \mathrm{HCl}, \mathrm{NaOtBu}$, anhydrous DMF, reflux, $\mathrm{N}_{2}, 4 \mathrm{~h}$ (iv) $\mathrm{BrCH}_{2} \mathrm{COOCH}_{3}, \mathrm{~K}_{2} \mathrm{CO}_{3}$, anhydrous acetone, 3 h; (v) (S)-(-) or (R)-(+)-2-phenylglycinol, TBTU, anhydrous THF, TEA, rt, $3 \mathrm{~h}$. 
Xanthones 1-4 have already been studied for their potential as inhibitors of bacterial resistance mechanisms [32], therefore, for this study, derivatives 5-12, 17, and 18 were tested. The structures of the compounds used herein were elucidated by nuclear magnetic resonance (NMR), Fourier-transform infrared spectroscopy (FTIR), and high-resolution mass spectrometry (HRMS). The optical rotation was also determined, and the enantiomeric purity was evaluated by chiral liquid chromatography (cLC). The $(S, S)$-Whelk-O1 ${ }^{\circledR}$ column and a mixture of $\mathrm{CH}_{3} \mathrm{CN} / \mathrm{CH}_{3} \mathrm{OH}(50: 50 \mathrm{v} / \mathrm{v})$ (compounds 11, 16, and 18) or 2-propanol $/ \mathrm{n}$ hexane/acetic acid (80:20:0.1 v/v) (compound 17) were chosen as mobile phase, based on the experience of our group $[45,46]$. Generally, the enantiomeric ratio (e.r.) values for all xanthone derivatives were higher than $99 \%$, as exemplified in Figure 1 for the enantiomeric pair 16. The optical rotation and e.r. values of the new chiral xanthones can be found in Section 3.1.

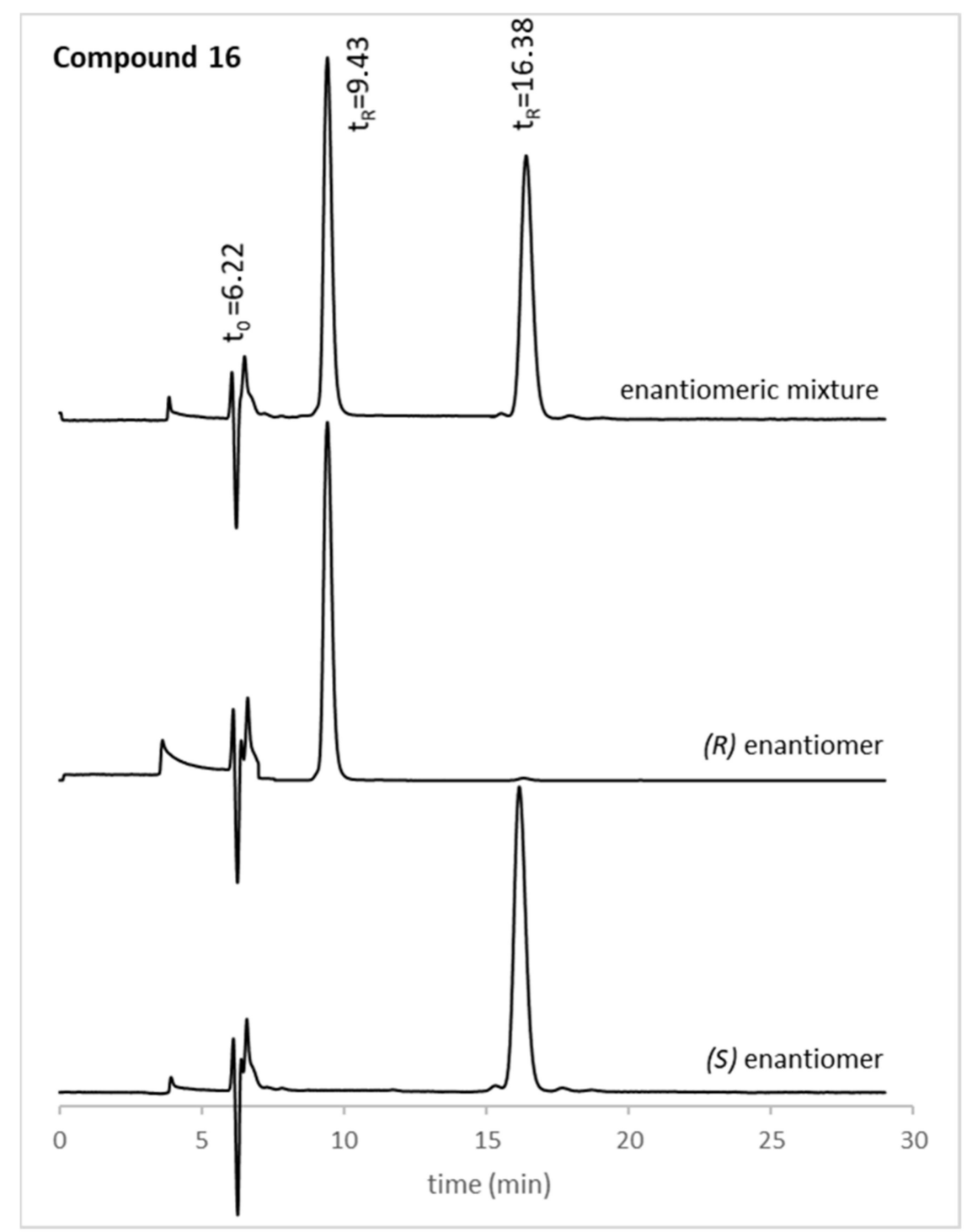

Figure 1. Chromatograms for the enantioseparation of the enantiomeric mixture 16, at optimized chromatographic conditions.

\subsection{Docking Studies}

The potential of the 10 synthesized chiral xanthones (both enantiomers of $\mathbf{8}, \mathbf{1 1}$, and 16-18), as well as 6 precursors (5-7, 9, 10, and 12), as bacterial efflux pump inhibitors, was investigated through docking studies. These were aimed at comparing the results obtained with compounds previously described as bacterial efflux pump inhibitors. The models used 
were the three components of the AcrAB-TolC efflux pump, an efflux system that belongs to the resistance-nodulation-division (RND) family, which is relevant in Gram-negative bacteria, and are deposited in the Protein Data Bank (AcrA: 2F1M; AcrB: 4DX5; TolC: 1EK9) and the NorA efflux pump, which belongs to the major facilitator superfamily (MFS) and is predominantly found in Gram-positive bacteria. NorA does not have crystal structure deposited in the Protein Data Bank, therefore, a homology model was built and used for the docking studies. The sites studied were sites described as important in the literature. For the periplasmic adaptor AcrA, the helical hairpin (HH) and the lipoyl domain (LD) were chosen [47]. The transmembrane pump AcrB was described to have a substrate-binding site (SBS) and a hydrophobic trap (HT), whose residues were picked for these studies [48], and the outer membrane channel TolC, was studied in the site comprised by the lysine residues that interact with the $3,3^{\prime}$-dithiobis(sulfosuccinimidyl propionate) bifunctional crosslinker [47]. The homology model of NorA was built as previously described [49], and thus docking studies were performed in the sites used in the same study, which were the binding core region (BCR) and the cytoplasmic side (CS) [49]. Compounds with reported activity in the efflux systems of Gram-positive and Gram-negative were used as positive controls, such as reserpine, phenyl-arginyl- $\beta$-naphthylamide (PA $\beta N), D 13-9001$, doxorubicin, MBX-3132, and minocycline [50]. The results of the docking studies are shown in Table 1.

Table 1. Docking results for the studied compounds in bacterial efflux pumps.

\begin{tabular}{|c|c|c|c|c|c|c|c|}
\hline \multirow{3}{*}{ Compound } & \multicolumn{7}{|c|}{ Docking Score } \\
\hline & \multicolumn{2}{|c|}{ AcrA } & \multicolumn{2}{|c|}{ AcrB } & \multirow{2}{*}{ TolC } & \multicolumn{2}{|c|}{ NorA } \\
\hline & HH & LD & SBS & HT & & BCR & CS \\
\hline 5 & -6.1 & -6.8 & -7.5 & -4.9 & -6.5 & -5.8 & -5.3 \\
\hline 6 & -5.7 & -5.6 & -7.3 & -5.3 & -6.5 & -6.5 & -6.4 \\
\hline 7 & -6.0 & -5.9 & -8.0 & -4.4 & -7.0 & -6.1 & -5.5 \\
\hline$(S, S)-8$ & -7.7 & -6.3 & -7.6 & -5.2 & -7.1 & -7.7 & -5.8 \\
\hline$(R, R)-8$ & -6.9 & -5.8 & -8.3 & -5.2 & -7.1 & -5.9 & -5.0 \\
\hline 9 & -5.9 & -5.8 & -7.3 & -5.2 & -6.5 & -6.1 & -5.8 \\
\hline 10 & -5.8 & -6.2 & -7.3 & -5.1 & -6.7 & -6.2 & -5.8 \\
\hline$(S)-11$ & -7.4 & -5.4 & -7.6 & 1.6 & -7.9 & -8.1 & -5.6 \\
\hline (R)-11 & -6.7 & -4.8 & -7.3 & -6.1 & -7.8 & -7.8 & -5.6 \\
\hline 12 & -5.7 & -5.7 & -6.9 & -5.6 & -6.7 & -5.4 & -5.3 \\
\hline$(S)-16$ & -6.8 & -6.0 & -8.9 & -6.9 & -7.5 & -7.2 & -6.4 \\
\hline$(R)-16$ & -6.6 & -6.4 & -9.1 & -6.7 & -7.8 & -5.2 & -6.0 \\
\hline (S)-17 & -7.3 & -6.2 & -9.2 & 3.2 & -7.9 & -7.0 & -5.2 \\
\hline$(R)-17$ & -7.0 & -5.5 & -8.5 & 0.0 & -8.1 & -8.7 & -5.1 \\
\hline$(S, R)-18$ & -7.5 & -6.9 & -9.6 & -7.2 & -9.0 & -5.9 & -6.5 \\
\hline$(R, S)-18$ & -7.3 & -5.8 & -9.8 & -7.1 & -8.4 & -7.1 & -5.7 \\
\hline Reserpine & 5.6 & 4.6 & -8.7 & 10.9 & -7.5 & 1.0 & -4.6 \\
\hline $\mathbf{P A} \beta \mathbf{N}$ & -5.8 & -4.9 & -7.1 & -4.7 & -7.1 & -9.4 & -5.3 \\
\hline D13-9001 & -6.2 & -5.1 & -9.7 & 26.5 & -7.4 & ND & ND \\
\hline Doxorubicin & -7.2 & -5.6 & -8.9 & 15.4 & -7.2 & ND & ND \\
\hline MBX-3132 & -7.9 & -6.2 & -7.9 & 2.9 & -7.7 & ND & ND \\
\hline Minocycline & -6.2 & -5.4 & -8.7 & 26.7 & -7.7 & ND & ND \\
\hline
\end{tabular}

SBS: Substrate-binding site; HT: Hydrophobic trap; HH: Helical hairpin; LD: Lipoyl domain; BCR: Binding core region; CS: Cytoplasmic side; ND: Not determined.

From the analysis of Table 1, some conclusions can be inferred. First, it can be noted that, as a general premise, the compounds were predicted to act similarly to the positive controls tested herein. Within the AcrAB-TolC efflux system, compounds present the most favorable predicted affinities towards the AcrB portion, specifically the SBS, and the least favorable for AcrA, similarly to the previously described for simple oxygenated xanthones [32]. 
The analysis of the enantiomeric pairs also led to interesting remarks, as their predicted affinities were different between the two enantioderivatives. For instance, the $S$-enantiomer of compound $\mathbf{8}$ has a better-predicted affinity for the AcrA portion and the NorA efflux pump, while the $R$-enantiomer is predicted to have a better fit in the AcrB portion, and both enantiomers appear to interact with TolC in the same manner, as their docking scores were the same. Compound $\mathbf{1 1}$ shows a notable difference concerning the HT of AcrB, with the $R$-enantiomer presenting a much favorable docking score for this site. The other compounds present values similar to what was described for compound 8, which led to hypothesize that the substituents linked to the chiral center may be involved in the interactions of these compounds with the referred targets.

\subsection{Antimicrobial Activity and Synergy with Antimicrobials}

Compounds 5-12 and 16-18 were evaluated for their antimicrobial activity against three Gram-negative bacterial strains, Escherichia coli ATCC 25922, Pseudomonas aeruginosa ATCC 27853 and Salmonella enterica serovar Typhimurium SL1344 (SE03), with the acrA gene deleted, and three Gram-positive strains, Staphylococcus aureus ATCC 29213, Enterococcus faecalis ATCC 29212 and the methicillin and ofloxacin-resistant clinical isolate S. aureus 272123. For the synergy assay, the extended-spectrum $\beta$-lactamase (ESBL)-producing $E$. coli SA/2 [51] was used, and the antibiotic cefotaxime (CTX) was chosen for observation of a decrease in the minimum inhibitory concentration. The antifungal activity of these compounds was also investigated for the yeast Candida albicans ATCC 10231, the filamentous fungi Aspergillus fumigatus ATCC 204305, and the dermatophyte Trichophyton rubrum FF5. The results show that no compound presented observable inhibition of bacterial growth, being their MIC values over $100 \mu \mathrm{M}$.

Concerning the synergy assay, compounds $\mathbf{6}$ and (S)-11 can decrease the MIC of CTX, a $\beta$-lactam to which E. coli SA/2 is resistant. The observed MIC of CTX in this bacterial strain was $562 \mu \mathrm{M}(256 \mu \mathrm{g} / \mathrm{mL})$, and it was decreased to $141 \mu \mathrm{M}(64 \mu \mathrm{g} / \mathrm{mL})$ in the presence of a non-toxic concentration of compounds 6 and (S)-11. This suggests that these compounds may be able to interact with ESBL and may pose a viable strategy to adopt in combination with antimicrobials. The fact that compounds 6 and $(S)-11$ do not present antibacterial activity, make them less prone to the appearance of resistances. Once again enantioselectivity was found.

All the tested compounds displayed MIC above $128 \mu \mathrm{g} / \mathrm{mL}$ for the fungal strains tested. The results obtained in these assays are summarized in Table S1 (Supplementary Data).

\subsection{Efflux Pump Inhibition}

In order to study the potential of the compounds to act as efflux pump inhibitors, 10 chiral derivatives and their precursors were studied for their ability to modulate the accumulation of ethidium bromide (EB), a known efflux pump substrate that can increase fluorescence when bound to DNA [52]. The bacteria chosen for this assay were the Grampositive $S$. aureus 272123, a clinical strain resistant to methicillin and ofloxacin, and the Gram-negative Salmonella Typhimurium SE03, with the acrA gene deleted, as this was predicted to be the portion of the efflux system to which the compounds would present the least affinity. These models were chosen to compare the activity of the derivatives herein present with the previously described activity of structurally related xanthones and thioxanthones [32,53].

The compounds were tested at $50 \mu \mathrm{M}$, as none presented antibacterial activity for the tested strains. Reserpine and carbonyl cyanide 3-chlorophenylhydrazone (CCCP) were chosen as positive controls for S. aureus 272123 and SE03, respectively, at the sub-MIC concentration of $25 \mu \mathrm{M}$. The results were expressed as the relative fluorescence index (RFI), which was calculated based on the mean of relative fluorescence units and can be seen in Table 2. 
Table 2. Relative fluorescence index (RFI) of the tested chiral xanthones and precursors.

\begin{tabular}{ccc}
\hline \multirow{2}{*}{ Compound } & \multicolumn{2}{c}{ RFI \pm SD } \\
\cline { 2 - 3 } & S. aureus $\mathbf{2 7 2 1 2 3}$ & SE03 \\
\hline $\mathbf{5}$ & $0.11 \pm 0.05$ & $0.10 \pm 0.01$ \\
$\mathbf{6}$ & $0.01 \pm 0.04$ & $0.05 \pm 0.07$ \\
$\mathbf{7}$ & $-0.14 \pm 0.01$ & $-0.06 \pm 0.04$ \\
$(\boldsymbol{S}, \boldsymbol{S}) \mathbf{- 8}$ & $-0.21 \pm 0.01$ & $2.23 \pm 0.05$ \\
$(\boldsymbol{R}, \boldsymbol{R})-\mathbf{8}$ & $3.19 \pm 0.31$ & $0.03 \pm 0.06$ \\
$\mathbf{9}$ & $0.03 \pm 0.03$ & $0.36 \pm 0.05$ \\
$\mathbf{1 0}$ & $-0.01 \pm 0.01$ & $-0.03 \pm 0.02$ \\
$(\boldsymbol{S}) \mathbf{- 1 1}$ & $-0.22 \pm 0.07$ & $0.05 \pm 0.07$ \\
$(\boldsymbol{R}) \mathbf{- 1 1}$ & $0.15 \pm 0.12$ & $-0.03 \pm 0.07$ \\
$\mathbf{1 2}$ & $0.14 \pm 0.03$ & $0.28 \pm 0.02$ \\
$(\boldsymbol{S})-\mathbf{1 7}$ & $0.05 \pm 0.04$ & $0.13 \pm 0.05$ \\
$(\boldsymbol{R}) \mathbf{- 1 7}$ & $0.30 \pm 0.02$ & $4.64 \pm 0.23$ \\
$(\boldsymbol{S}, \boldsymbol{R}) \mathbf{- 1 8}$ & $0.05 \pm 0.01$ & $0.02 \pm 0.06$ \\
$(\boldsymbol{R}, \boldsymbol{S}) \mathbf{- 1 8}$ & $0.26 \pm 0.07$ & $0.96 \pm 0.04$ \\
Reserpine & $0.42 \pm 0.13$ & ND \\
CCCP & ND & $0.44 \pm 0.03$ \\
\hline
\end{tabular}

SE03: S. enterica serovar Typhimurium SL1344; SD: Standard deviation; CCCP: Carbonyl cyanide 3chlorophenylhydrazone; ND: Not determined.

The analysis of the RFI showed that one compound, $(R, R)-8$, was effective in increasing the relative fluorescence in $S$. aureus 272123 in a higher level than reserpine. On the other hand, three compounds were effective in the display of the same effect in SE03, $(S, S)-8$, $(R)-17$ and $(R, S)-18$. This event could be attributed to the inhibition of EB efflux, but also to the fluorescence of the compounds. As such, the RFI of the compound alone and in combination with EB was measured over the same period in order to observe if the compounds displayed an erratic pattern of fluorescence. The results obtained led to the conclusion that the fluorescence observed are due to the inhibition of the efflux of EB, as the compounds displayed almost no fluorescence by themselves and the same fluorescence as EB when applied in combination with it (results not shown). It can also be noted that some compounds present negative RFI values, which means that their relative fluorescence indexes are lower than that of the negative control, dimethyl sulfoxide (DMSO, $1 \% v / v$ ), and were considered ineffective for this purpose. Figure 2 shows the comparison between the effective compounds and the positive controls.

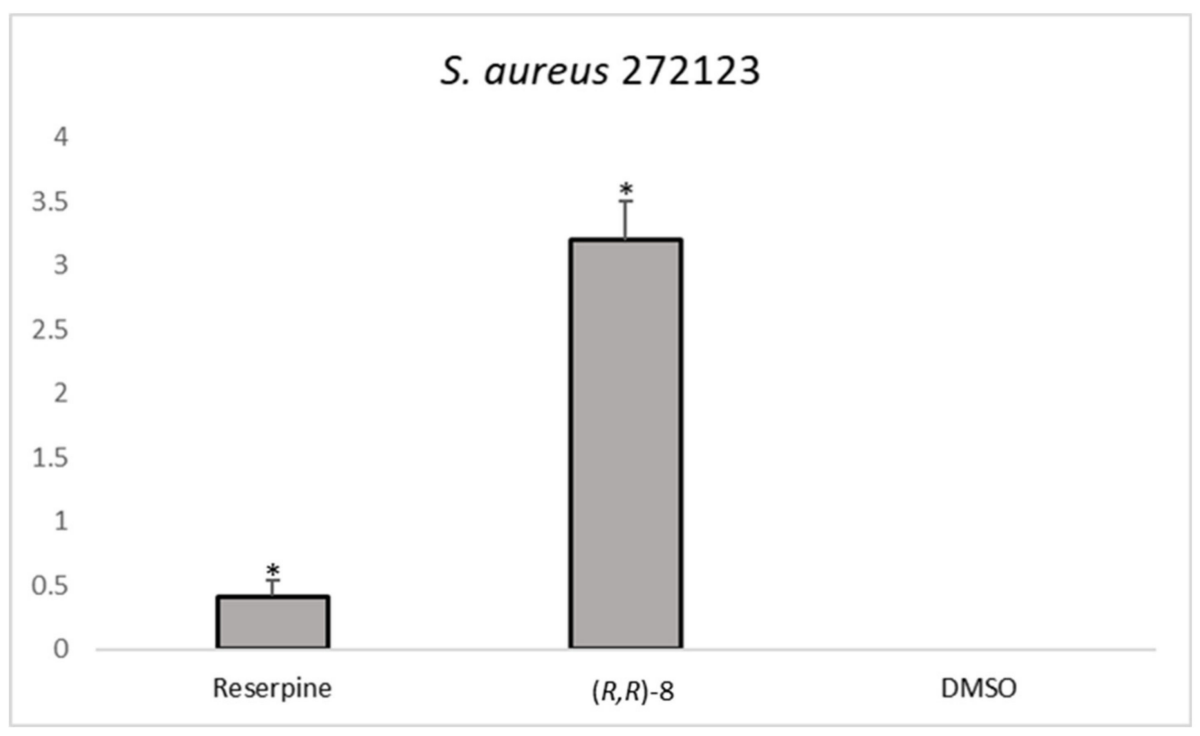

Figure 2. Cont. 


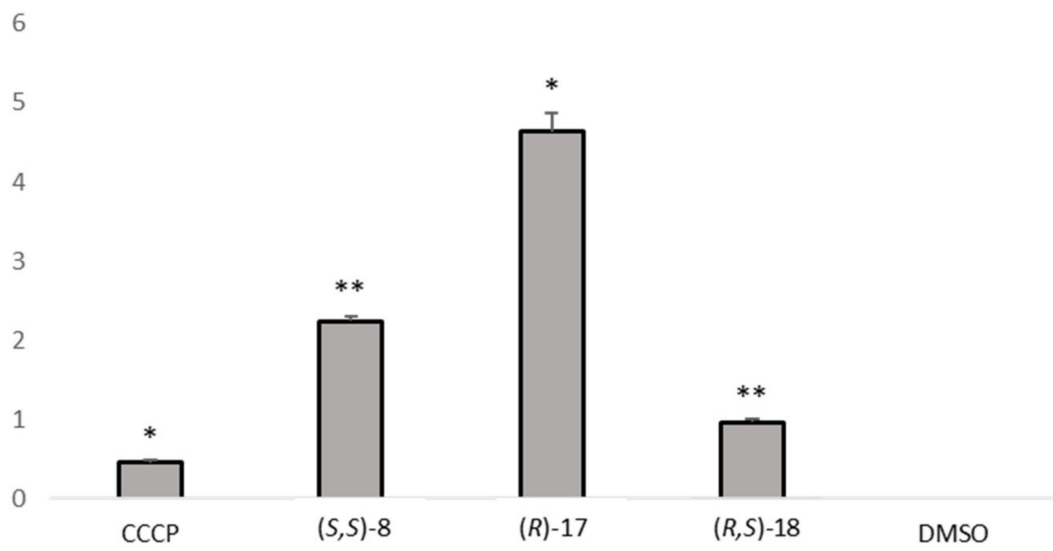

Figure 2. Comparison of the RFI of different compounds to those of the positive controls [S. aureus 272123 (top); SE03 (bottom)]. Results are presented as mean \pm SD. Statistical comparisons were performed using the $t$-test $\left[{ }^{*} p<0.05 ;{ }^{* *} p<0.01\right.$ vs. control (DMSO $\left.\left.1 \% v / v\right)\right]$.

Generally, none of the enantiomeric pairs showed activity for the same pump being the efflux pump inhibitory effect enantioselective. Noteworthy, the achiral precursors 5-7, 9, 10, and 12 did not display favorable results for this activity.

Considering these results, a possible binding site was investigated for these compounds, using PyMol program for visual inspection. According to the initial docking studies performed (Table 1$)$, compound $(\boldsymbol{R}, \boldsymbol{R})-\mathbf{8}$ was visualized in the BCR of the NorA homology model, whereas compounds $(S, S)-\mathbf{8},(R)-\mathbf{1 7}$ and $(R, S)-\mathbf{1 8}$ were visualized in the SBS of the AcrB portion.

In the interactions of $(\boldsymbol{R}, \boldsymbol{R})-8$ in NorA, it can be seen that the substituent in the C3 position was predicted to play an important role in binding to this portion of the efflux system. The amide establishes a hydrogen bond with Glu-222, as did structurally-related thioxanthones previously tested [53], and the hydroxyl moiety can do the same with Phe288, as can be seen in Figure 3A. Besides, this compound seems to fit perfectly in a pocket present in this site (Figure $3 \mathrm{~B}$ ). Interestingly, its enantiomer $(\boldsymbol{S}, \mathbf{S})-\mathbf{8}$ was predicted to bind with the most affinity in a different site of the BCR, as the two phenyl groups seem to establish a $\pi-\pi$ stacking, making the position of the molecule too hindered to enter the pocket where $(\boldsymbol{R}, \boldsymbol{R})-\mathbf{8}$ is predicted to bind (Figure $3 C)$.

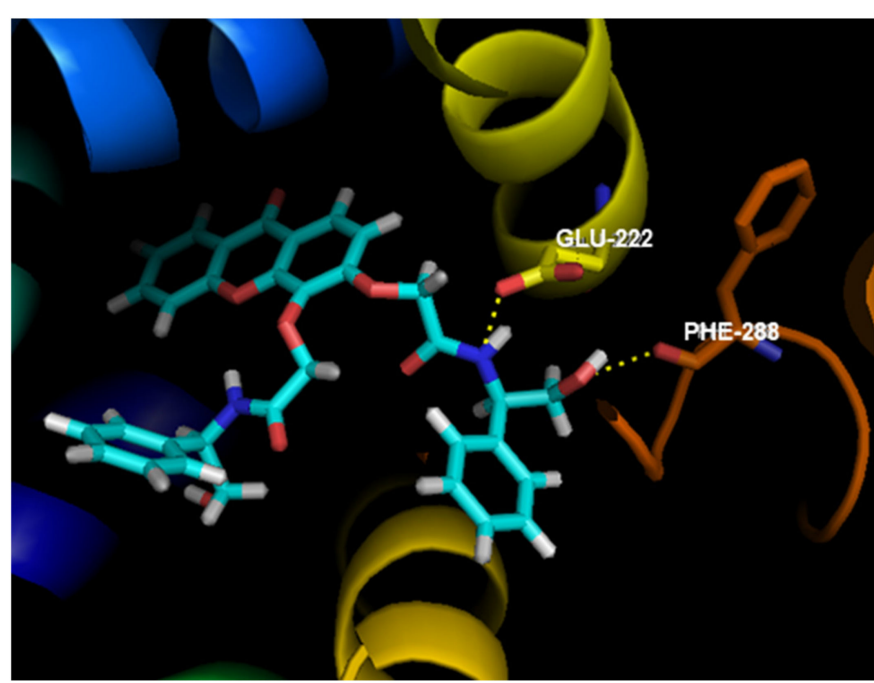

(A)

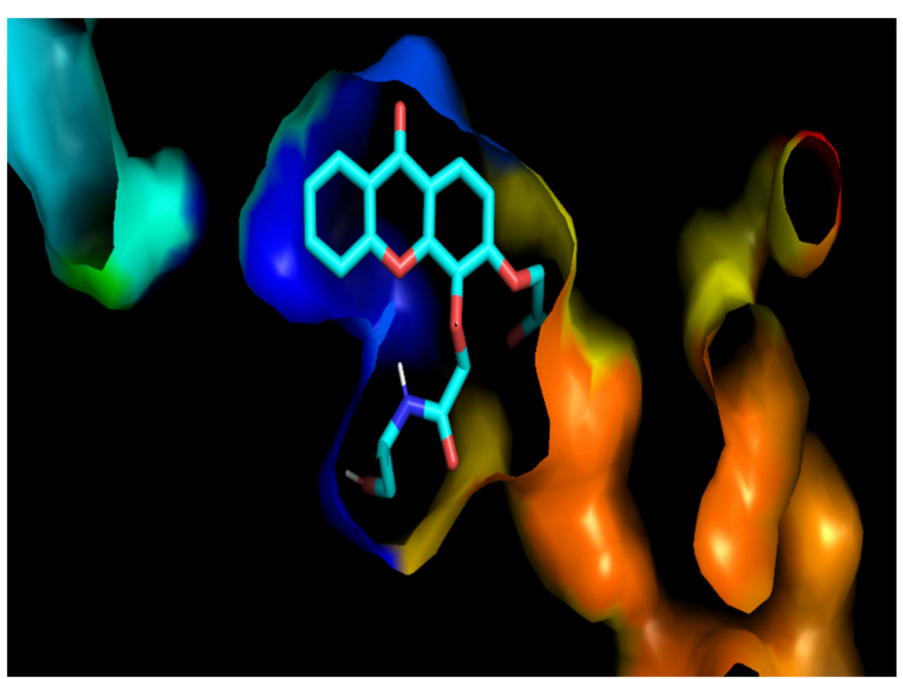

(B)

Figure 3. Cont. 


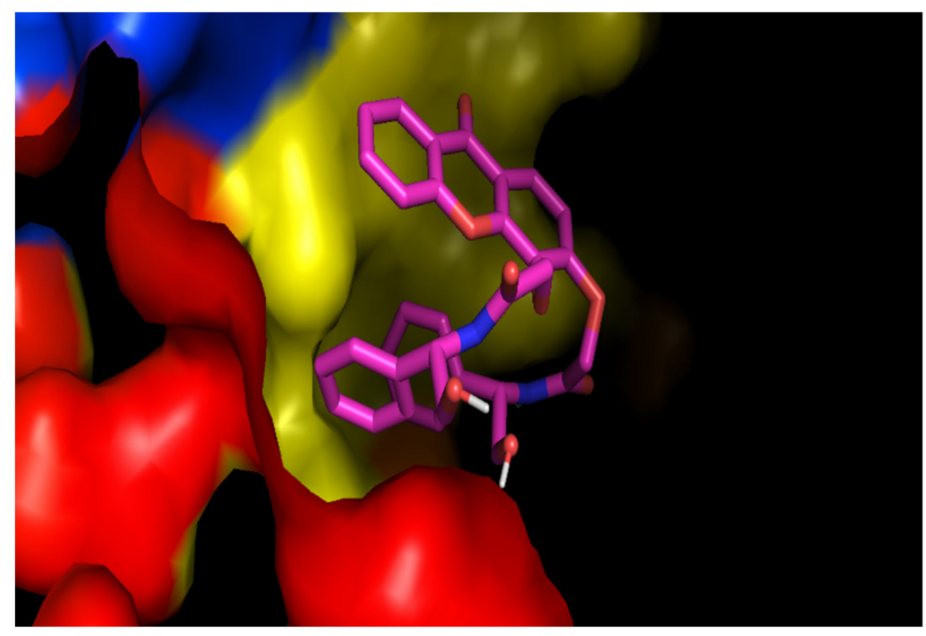

(C)

Figure 3. Molecular visualization of $(R, R)-8$ (blue) and $(S, S)-8$ (pink) in the BCR of the homology model of NorA; $(\mathrm{A})$ interaction of $(\boldsymbol{R}, \boldsymbol{R})-\mathbf{8}$ with key residues; $(\mathrm{B})$ surface view of $(\boldsymbol{R}, \boldsymbol{R})-\mathbf{8}$ inside a pocket; $(\mathbf{C})$ visualization of $(S, S)-\mathbf{8}$ at the surface of the homology model.

Concerning the visualization in $\mathrm{AcrB}$, the enantiomeric pair $\mathbf{8}$ is predicted to have a very different behavior than in the homology model of NorA, in accordance to experimental results. As can be seen in Figure $4 \mathrm{~A}$, compound $(S, S)-8$, which presented activity in the accumulation assay, spreads over a larger area than $(R, R)-8$. A deeper analysis of $(S, S)$ 8 shows interactions with Ser-46, Ser-128, Lys-163, Asn-274, and Arg-767 (Figure 4B). Previous studies showed that nitrogen-substituted thioxanthones also formed hydrogen bonds with Arg-274, and residues nearby the other described [32].

Compound $(R)-17$ was predicted to interact with several residues previously described for xanthones and thioxanthones, such as Gln-89, Gln-176, and Gly-619 [32,53]. Additionally, this compound also interacts with Ser-180, Gln-181, and Gln-273 (Figure 4C). Lastly, compound $(R, S)-\mathbf{1 8}$ is predicted to establish hydrogen bonds mostly with residues previously described in other studies with (thio)xanthones, such as Thr-87. Gln-176 and Arg-620 [32,53]. The hydroxyl present in the compound can establish an additional hydrogen bond with Lys-292 (Figure 4D). Additionally, all the compounds presented non-polar interactions (not shown).

Doxorubicin is a known AcrB substrate, that has been co-crystallized with this portion of the AcrAB-TolC efflux system [54]. It possesses a tetracyclic scaffold, similar to the tricyclic scaffold of the xanthones presented herein, which led us to also analyze the predicted interactions between this drug and AcrB (Figure 4E), and were found to be similar to previously described $[48,54]$. Firstly, it can be noted that the carbonyl moiety on the carboxylic acid side chain of doxorubicin interacts with Thr-87. Compound $(\boldsymbol{R}, S)-\mathbf{1 8}$ is also predicted to establish this interaction, specifically due to the carbonyl in the xanthone moiety. The amine in doxorubicin can establish a polar interaction with Ser-128, similar to what was described for the carbonyl in the amide present is compound $(\boldsymbol{R}, \boldsymbol{R})-\mathbf{8}$. Another residue that was predicted to be involved in the binding of doxorubicin, $(R)-17$ and $(R, S)$ 18 was Gln-176, where a carbonyl of doxorubicin and the ether present in the xanthone scaffold were predicted to establish polar interactions. Doxorubicin also presents polar interactions with Gly-126, Gly-179, and Lys-770.

Although the results herein presented suggest the inhibition of efflux pumps, it cannot be ruled out that the compounds present other mechanisms that led to the results obtained. Further studies are warranted in order to clarify this subject. 

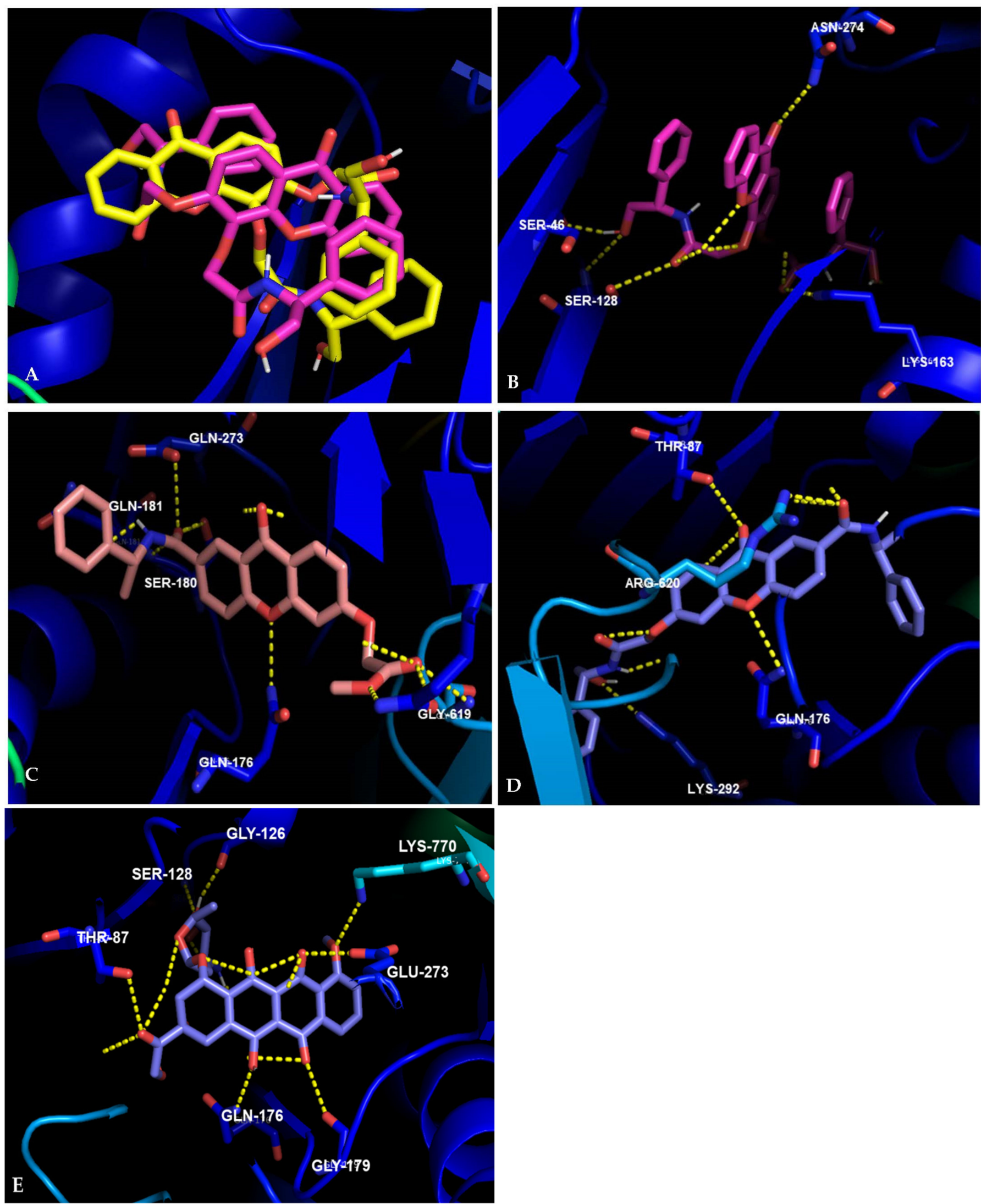

Figure 4. Molecular visualization of the effective compounds in the SBS of AcrB. (A) $(R, R)-8$ (yellow) and $(S, S)-8$ (pink) in the SBS of AcrB; $(\mathbf{B})$ interactions of $(S, S)-8$ with key residues; $(C)$ interactions of $(R)-\mathbf{1 7}$ with key residues; (D) interactions of $(R, S)-18$ with key residues; $(E)$ interactions of doxorubicin with key residues. 


\subsection{Inhibition of Biofilm Formation and Quorum-Sensing}

The chiral compounds were studied for their ability to inhibit the formation of biofilm and QS. As these mechanisms are related to the inhibition of efflux pumps $[55,56]$, only the compounds that displayed inhibition of EB efflux in Section 2.4, $(S, S)-\mathbf{8},(R, R)-\mathbf{8},(R)-\mathbf{1 7}$, and $(R, S)-18$, were tested. In fact, aside from the efflux of xenobiotics from the interior of the bacterial cell, efflux pumps induce the efflux of substances that are responsible for the formation of biofilms, and the transport of quorum-sensing molecules, e.g., acyl homoserine lactones (AHL). They are also involved in the regulation of genes involved in these phenomena and in the modulation of aggregation between bacteria and between bacteria and surfaces [57].

The biofilm formation assay was performed against S. aureus ATCC 29213 and S. aureus 272123. For this assay, reserpine was used as a positive control, as it is both an inhibitor of efflux pumps and biofilm $[50,58]$. The inhibition of biofilm formation, prevention of the adhesion or degradation was expressed in percentage (\%) and was calculated based on the mean of the absorbance units. All the compounds were tested at $100 \mu \mathrm{M}$, as no compounds presented antibacterial activity at this concentration for the strains tested. The results obtained in this assay are depicted in Table 3.

All the compounds were more active in S. aureus 272123 than in the ATCC strain, as the compounds had no influence in the biofilm formation in the latter, although less effective than reserpine. Interestingly, compound $(\boldsymbol{R}, \boldsymbol{R})-\mathbf{8}$, which was the most active on biofilm inhibition, was also the only compound able to inhibit efflux pumps in $S$. aureus 272123, suggesting a possible related mechanism.

The ability of these compounds to inhibit QS was also investigated. For that, four Gram-negative bacteria were used: the sensor strain Chromobacterium violaceum CV026 (CV026), which was inoculated as a parallel line to Sphingomonas paucimobilis Ezf 10-17 (EZF), a producer strain of AHL, and the AHL producers Serratia marcescens AS-1 and Chromobacterium violaceum wild-type 85 (wt 85 ), which were inoculated as single lines. Promethazine (PMZ) was used as positive control, and the inhibition of QS was observed as the reduction in pigment production and measured in millimeters $(\mathrm{mm})[59,60]$. The results are present in Table 3.

Interestingly, only the compounds corresponding to the enantiomeric pair 8 displayed inhibition of QS in the system EZF + CV026. Even though bacteria of the Chromobacterium species have been proven to present RND efflux pumps [61], a causative relationship between the inhibition of these pumps and QS could not be established at this point, but is a topic that deserves deeper studies.

Table 3. Biofilm and quorum sensing inhibition of the chiral xanthones tested.

\begin{tabular}{|c|c|c|c|c|c|}
\hline \multirow{2}{*}{ Compound } & \multicolumn{2}{|c|}{ Biofilm Inhibition $(\%) \pm \mathrm{SD}$} & \multicolumn{3}{|c|}{ Quorum Sensing Inhibition $(\mathrm{mm}) \pm \mathrm{SD}$} \\
\hline & $\begin{array}{c}\text { S. aureus ATCC } \\
29213\end{array}$ & S. aureus 272123 & S. marcescens & wt85 & $\mathrm{EZF}+\mathrm{CV} 026$ \\
\hline$(S, S)-8$ & 0 & $7.85 \pm 1.95$ & 0 & 0 & $47 \pm 0.1$ \\
\hline$(R, R)-8$ & 0 & $55.59 \pm 3.26$ & 0 & 0 & $31 \pm 0.8$ \\
\hline (R)-17 & 0 & $46.23 \pm 1.19$ & 0 & 0 & 0 \\
\hline$(R, S)-18$ & 0 & $21.04 \pm 1.47$ & 0 & 0 & 0 \\
\hline Reserpine & $22.29 \pm 5.10$ & $63.1 \pm 2.33$ & ND & ND & ND \\
\hline PMZ & ND & ND & $18 \pm 0.8$ & $40 \pm 0.1$ & $41 \pm 0.5$ \\
\hline
\end{tabular}

CV026; SD: Standard deviation; PMZ: Promethazine; ND: not determined.

\section{Materials and Methods}

All reagents and solvents used for the synthesis were purchased from Sigma Aldrich (Sigma-Aldrich Co. Ltd., Gillinghan, UK) and were not subject to any purification process. A rotary evaporator Buchi Rotavap R-210 and a Buchi Heating Bath B-491 were used to evaporate the solvents under reduced pressure, with a Huber mini-chiller ensuring refrigeration. Thin-layer chromatography (TLC) was carried out to monitor the reactions, on precoated plates with $0.2 \mathrm{~mm}$ of thickness using Merck silica gel $60\left(\mathrm{G} / \mathrm{UV}_{254}\right)$ using 
suitable mobile phases. The compounds herein described were easily detectable at $254 \mathrm{~nm}$ or $365 \mathrm{~nm}$.

The synthesized products were purified by flash column chromatography, using silica gel 60 (0.040-0.063 mm, Acros Organics, Geel, Belgium). Melting points (mp) were measured in a Köfler microscope (Wagner and Munz, Munich, Germany) and were uncorrected. For structure elucidation, ${ }^{1} \mathrm{H}$ - and ${ }^{13} \mathrm{C}$-nuclear magnetic resonance (NMR) spectra were recorded at room temperature on a Bruker Avance 300 spectrometer $\left(300.13 \mathrm{MHz}\right.$ for ${ }^{1} \mathrm{H}$ and $75.47 \mathrm{MHz}$ for ${ }^{13} \mathrm{C}$, Bruker Biosciences Corporation, Billerica, MA, USA), at the Department of Chemistry, University of Aveiro. The samples were solubilized in DMSO- $d_{6}$ or $\mathrm{CDCl}_{3}$. (Aldrich, Steinheim, Germany). Chemical shifts are shown in $\delta(\mathrm{ppm})$ values relative to tetramethylsilane (TMS), used as an internal reference. Coupling constants are reported in hertz (Hz). The assignments of ${ }^{13} \mathrm{C}-\mathrm{NMR}$ were made by bidimensional heteronuclear single quantum coherence (HSQC) and heteronuclear multiple bond correlation (HMBC) NMR experiments (long-range $\mathrm{C}, \mathrm{H}$ coupling constants were optimized to $7 \mathrm{~Hz}$ ) or by comparison with the assignments of similar molecules. High-resolution mass spectroscopy (HRMS) spectra were measured on a LTQ Orbitrap XL hybrid mass spectrometer (Thermo Fischer Scientific, Bremen, Germany) at CEMUP, University of Porto, Portugal. The optical rotations were recorded on a Polartronic Universal polarimeter (ADP 410 polarimeter).

The solvents used for cLC analysis $\left(\mathrm{CH}_{3} \mathrm{CN}, \mathrm{CH}_{3} \mathrm{OH}\right.$, 2-propanol, $n$-hexane, and acetic acid) were of high-performance liquid chromatography (HPLC) grade and purchased from Sigma-Aldrich (Sigma-Aldrich Co. Ltd., Gillinghan, UK). The stock solutions of the chiral derivatives of xanthone were prepared by dissolution in $\mathrm{CH}_{3} \mathrm{CH}_{2} \mathrm{OH}$ at a concentration of $1 \mathrm{mg} / \mathrm{mL}$ and further diluted to a concentration of $10 \mu \mathrm{g} / \mathrm{mL}$. Aliquots of each enantiomer were mixed to obtain working solutions. The e.r. measurements were performed with the stock solutions of each enantiomer diluted at a concentration of $20 \mu \mathrm{g} / \mathrm{mL}$.

The culture media used in the experiments were purchased: the cation-adjusted Mueller-Hinton broth (MHB II) was purchased from Sigma-Aldrich, St. Louis, MO, USA and Biokar Diagnostics, Allone, Beauvais, France, the Luria-Bertani broth (LB-B) from Sigma, St. Louis, MO, USA, Tryptic Soy broth (TSB) was bought from Scharlau Chemie S.A., Barcelona, Tryptic-Soy agar (TSA) was purchased from Biokar Diagnostics, Allone, Beauvais, France), Sabouraud Dextrose Agar (SDA) from bio-Mérieux, Marcy L'Etoile, France, RPMI-1640 broth medium from Biochrom AG, Berlin, Germany, which was buffered with 3-( $N$-morpholino) propanesulfonic acid (MOPS), purchased from Sigma-Aldrich, St. Louis, MO, USA, to $\mathrm{pH}$ 7.0. The modified Luria-Bertani agar (LB*-A) was prepared in-house, according to the formula: $1.0 \mathrm{~g}$ yeast extract (Merck, Darmstadt, Germany), $10.0 \mathrm{~g}$ tryptone (Biolab, Budapest, Hungary), $10.0 \mathrm{~g} \mathrm{NaCl}$ (Molar Chemicals, Halásztelek, Hungary), $1.0 \mathrm{~g} \mathrm{~K}_{2} \mathrm{HPO}_{4}$ (Biolab, Budapest, Hungary), $0.3 \mathrm{~g} \mathrm{MgSO}_{4} \times 7 \mathrm{H}_{2} \mathrm{O}$ (Reanal, Budapest, Hungary), $5 \mathrm{~mL}$ Fe-EDTA stock solution and $20.0 \mathrm{~g}$ of bacteriological agar (Molar Chemicals, Halásztelek, Hungary) per 1 L of media.

Dimethyl sulfoxide (DMSO), phosphate-buffered saline (PBS; $\mathrm{pH}$ 7.4), ethidium bromide (EB), reserpine, carbonyl cyanide 3-chlorophenylhydrazone (CCCP), promethazine (PMZ) and crystal violet (CV) were purchased from Sigma-Aldrich Chemie GmbH (Steinheim, Germany). The antibiotic cefotaxime (CTX) was purchased from Duchefa Biochemie (Haarlem, The Netherlands). Bacteria were purchased from ATCC.

\subsection{Chemistry}

The syntheses of compounds 1-8 [62] and 13-15 [44] were previously reported. Compound 1 was obtained through a benzophenone route, as described previously. After its demethylation different products could be obtained. The main product was the 3methoxy-4-hydroxy-9H-xanthen-9-one (2), although the formation of secondary products, 3-hydroxy-4-methoxy-9H-xanthen-9-one (4) and 3,4-dihydroxy-9H-xanthen-9-one (3) occurred [62].

Starting from 3, the derivatives 6,7 , and 8 were obtained, as previously described [62], with yields of $95 \%, 81 \%$, and $57 \%$, respectively. The synthesis of compounds $\mathbf{9 - 1 2}$ will be 
detailed in Sections 3.1.1-3.1.4. The synthesis of derivatives 16-18 was accomplished using 13 as a starting material, which was obtained via Ullmann reaction, which then yielded compounds 14 (50\%) and 15 (95\%), following the procedure in [44]. Detailed descriptions can be found in Sections 3.1.5-3.1.7.

\subsubsection{Synthesis of Methyl 2-[(3-Methoxy-9-oxo-9H-xanthen-4-yl)oxy]acetate (9)}

Methyl 2-[(3-methoxy-9-oxo-9H-xanthen-4-yl)oxy]acetate (9) was prepared from 3methoxy-4-hydro-9H-xanthen-9-one (2), using the same method as previously described for $2^{\prime}$-[(9-oxo-9H-xanthene-3,4-diyl)bis(oxy)]diacetate (6), adjusting the amount of $\mathrm{K}_{2} \mathrm{CO}_{3}$ and $\mathrm{BrCH}_{2} \mathrm{COOCH}_{3}$ according to the number of hydroxyl groups of the chemical substrate and the stoichiometry of the reaction [62]. The product was purified by flash chromatography ( $n$-hexane/ethyl acetate in gradient) affording 9 as white solid.

Yield: $40 \%$. m.p.: $135-138{ }^{\circ} \mathrm{C}$. IR $v_{\max }\left(\mathrm{cm}^{-1}\right)(\mathrm{KBr}): 1750.8,1603.4,1509.1,1464.6$, 1388.0, 1288.2, 1216.3, 1033.5, 819.5, 767.6. ${ }^{1} \mathrm{H}$ NMR (300.13 MHz, DMSO-d 6 ) $\delta: ~ 8.17(\mathrm{dd}$, $J=7.9,1.7 \mathrm{~Hz}, 1 \mathrm{H}, \mathrm{H}-8), 7.95(\mathrm{~d}, J=9.0 \mathrm{~Hz}, 1 \mathrm{H}, \mathrm{H}-1), 7.85(\mathrm{ddd}, J=8.4,7.2,1.7 \mathrm{~Hz}, 1 \mathrm{H}$, H-6), 7.63 (dd, $J=8.4,1.7 \mathrm{~Hz}, 1 \mathrm{H}, \mathrm{H}-5), 7.47$ (ddd, $J=7.9,7.2,1.7 \mathrm{~Hz}, 1 \mathrm{H}, \mathrm{H}-7), 7.27$ (d, $J=9.0 \mathrm{~Hz}, 1 \mathrm{H}, \mathrm{H}-2), 4.85\left(\mathrm{~s}, 2 \mathrm{H}, \mathrm{OCH}_{2}\right), 3.73\left(\mathrm{~s}, 3 \mathrm{H}, \mathrm{OCH}_{3}\right), 3.36\left(\mathrm{~s}, 3 \mathrm{H}, \mathrm{COOCH}_{3}\right) .{ }^{13} \mathrm{C}$ NMR (75.47 MHz, DMSO-d 6 ) $\delta: 175.2$ (C-9), $169.1\left(\mathrm{COOCH}_{3}\right), 156.7$ (C-3), $155.5(\mathrm{C}-4)$, 149.4 (C-1), 135.3 (C-10a), 134.1 (C-4a), 125.9 (C-2), 124.4 (C-6), 121.7 (C-8), 120.8 (C-7), 118.1 (C-5), 115.8 (C-8a), $109.7(\mathrm{C}-9 \mathrm{a}), 69.3\left(\mathrm{OCH}_{2}\right), 56.6\left(\mathrm{OCH}_{3}\right), 51.7\left(\mathrm{COOCH}_{3}\right)($ Figure S1, Supplementary Data). HRMS (ESI+): $m / z\left[\mathrm{C}_{17} \mathrm{H}_{14} \mathrm{O}_{6}+\mathrm{H}\right]+$ calcd. for $\left[\mathrm{C}_{17} \mathrm{H}_{15} \mathrm{O}_{6}\right]$ : 315.08687; found 315.08569 (Figure S2, Supplementary Data).

\subsubsection{Synthesis of 2-[(3-Methoxy-9-oxo-9H-xanthen-4-yl)oxy]acetic Acid (10)}

Compound 10 was prepared from 9, using the same method as described for 2,2'-[(9oxo-9H-xanthene-3,4-diyl)bis(oxy)]diacetic acid (7), adjusting the volume of the solution of $5 \mathrm{M} \mathrm{NaOH}$ according to the number of acetate groups of the chemical substrate and the stoichiometry of the reaction [62], yielding 2-[(3-methoxy-9-oxo-9H-xanthen-4-yl)oxy]acetic acid (10) as white solid.

Yield: $97 \%$. m.p.: $205-208{ }^{\circ} \mathrm{C}$. IR $v_{\max }\left(\mathrm{cm}^{-1}\right)(\mathrm{KBr}): 3204.0,2925.0,1758.6,1604.1$, 1585.2, 1467.8, 1290.4, 1229.6, 1033.1, 819.1, 766.6. ${ }^{1} \mathrm{H}$ NMR (300.13 MHz, DMSO-d 6 ) $\delta: 12.9$ (s, $1 \mathrm{H}, \mathrm{COOH}), 8.17(\mathrm{dd}, J=8.0,1.7 \mathrm{~Hz}, 1 \mathrm{H}, \mathrm{H}-8), 7.90(\mathrm{~d}, J=9.0 \mathrm{~Hz}, 1 \mathrm{H}, \mathrm{H}-1), 7.80(\mathrm{ddd}, J$ $=8.6,7.2,1.7 \mathrm{~Hz}, 1 \mathrm{H}, \mathrm{H}-6), 7.64(\mathrm{dd}, J=8.6,1.7 \mathrm{~Hz}, 1 \mathrm{H}, \mathrm{H}-5), 7.48(\mathrm{ddd}, J=8.0,7.2,1.7 \mathrm{~Hz}$, 1H, H-7), $7.27(\mathrm{~d}, J=9.0 \mathrm{~Hz}, 1 \mathrm{H}, \mathrm{H}-1), 4.76\left(\mathrm{~s}, 2 \mathrm{H}, \mathrm{OCH}_{2}\right), 3.97\left(\mathrm{~s}, 3 \mathrm{H}, \mathrm{OCH}_{3}\right) .{ }^{13} \mathrm{C} \mathrm{NMR}$ (75.47 MHz, DMSO- $\left.d_{6}\right) \delta: 175.3$ (C-9), 170.1 (COOH), 156.7 (C-3), 155.5 (C-4), 149.4 (C-1), 135.3 (C-10a), 134.3 (C-4a), 125.9 (C-2), 124.4 (C-6), 121.5 (C-8), 120.8 (C-7), 118.2 (C-5), 115.9 (C-8a), $109.8(\mathrm{C}-9 \mathrm{a}), 69.2\left(\mathrm{OCH}_{2}\right), 56.6\left(\mathrm{OCH}_{3}\right)$ (Figure S3, Supplementary Data). HRMS (ESI+): $m / z\left[\mathrm{C}_{16} \mathrm{H}_{12} \mathrm{O}_{6}+\mathrm{H}\right]+$ calcd. for $\left[\mathrm{C}_{16} \mathrm{H}_{13} \mathrm{O}_{6}\right]$ : 301.07122; found 301.07191 (Figure S4, Supplementary Data).

3.1.3. Synthesis of (S)-2-[(3-Methoxy-9-oxo-9H-xanthen-4-yl)oxy]-N-(1-phenylethyl)acetamide [(S)-11] and (R)-2-[(3-Methoxy-9-oxo-9H-xanthen-4-yl)oxy]- $N$-(1-phenylethyl)acetamide [(R)-11]

The enantiomeric pair (S)-2-[(3-methoxy-9-oxo-9H-xanthen-4-yl)oxy]-N-(1-phenylethyl)acetamide [(S)-11] and (R)-2-[(3-methoxy-9-oxo-9H-xanthen-4-yl)oxy]-N-(1-phenylethyl)acetamide [(R)-11] was prepared from the carboxyl compound 10, using the same method as described for compound 8 [62], and the chiral reagents $(S)-(-)-(\alpha)$-methylbenzylamine and $(R)-(+)-(\alpha)$-methylbenzylamine, respectively. The final products were obtained as white solid.

(S)-2-[(3-Methoxy-9-oxo-9H-xanthen-4-yl)oxy]-N-(1-phenylethyl)acetamide [(S)-11] Yield: $45 \%$. m.p.: $164-167^{\circ} \mathrm{C}$. $[\alpha]_{\mathrm{D}}{ }^{25^{\circ} \mathrm{C}}+48.2\left(c=0.83 \times 10^{-3} \mathrm{gmL}^{-1}\right.$ in $\left.\mathrm{CH}_{3} \mathrm{OH}\right)$. e.r: $>$ 99\% (k: 1.40) (Figure S5, Supplementary Data).

(R)-2-[(3-Methoxy-9-oxo-9H-xanthen-4-yl)oxy]-N-(1-phenylethyl)acetamide [(R)-11]: Yield: $50 \%$. m.p.: $165-167^{\circ} \mathrm{C} .[\alpha]_{\mathrm{D}}{ }^{25^{\circ} \mathrm{C}}-48.4\left(c=0.83 \times 10^{-3} \mathrm{gmL}^{-1}\right.$ in $\left.\mathrm{CH}_{3} \mathrm{OH}\right)$. e.r: $>$ 99\% (k: 0.78) (Figure S5, Supplementary Data). 
IR $v_{\max }\left(\mathrm{cm}^{-1}\right)(\mathrm{KBr}): 3348.1,1665.1,1604.8,1587.5,1466.9,1289.1,1230.2,1023.4$, 817.7, 769.1. ${ }^{1} \mathrm{H}$ NMR (300.13 MHz, DMSO- $\left.d_{6}\right) \delta: 8.38(\mathrm{~d}, J=8.2 \mathrm{~Hz}, 1 \mathrm{H}, \mathrm{NH}), 8.17$ (dd $J=$ 8.0, $1.8 \mathrm{~Hz}, 1 \mathrm{H}, \mathrm{H}-8), 7.96(\mathrm{~d}, J=9.0 \mathrm{~Hz}, 1 \mathrm{H}, \mathrm{H}-1), 7.82$ (ddd, $J=8.7,7.1,1.8 \mathrm{~Hz}, 1 \mathrm{H}, \mathrm{H}-6)$, $7.50(\mathrm{dd}, J=8.7,1.8 \mathrm{~Hz}, 1 \mathrm{H}, \mathrm{H}-5), 7.46(\mathrm{ddd}, J=8.0,7.1,1.8 \mathrm{~Hz}, 1 \mathrm{H}, \mathrm{H}-7), 7.45-7.27$ (m, 5H, H-2" to H-6"), 7.26 (d, J = 9.0 Hz, 1H, H-2), $5.10\left(\mathrm{q}, J=8.2 \mathrm{~Hz}, 1 \mathrm{H}, \mathrm{H}-1^{\prime}\right), 4.65(\mathrm{~s}, 2 \mathrm{H}, \mathrm{OCH})^{\prime}$, $3.93\left(\mathrm{~s}, 3 \mathrm{H}, \mathrm{OCH}_{3}\right), 1.48\left(\mathrm{~d}, J=8.2 \mathrm{~Hz}, 3 \mathrm{H}, \mathrm{H}-2^{\prime}\right) .{ }^{13} \mathrm{C} \mathrm{NMR}\left(75.47 \mathrm{MHz}, \mathrm{DMSO}-d_{6}\right) \delta: 175.2$ (C-9), 167.1 (CONH), 156.6 (C-3), 155.4 (C-4), 149.3 (C-1), 135.2 (C-10a), 134.7 (C-4a), 128.4 $\left(\mathrm{C}-1^{\prime \prime}\right), 126.9\left(\mathrm{C}-3^{\prime \prime}\right.$ to $\left.\mathrm{C}-5^{\prime \prime}\right), 126.1\left(\mathrm{C}-2^{\prime \prime}\right.$ and $\left.\mathrm{C}-6^{\prime \prime}\right), 125.9(\mathrm{C}-2), 124.4(\mathrm{C}-6), 121.9(\mathrm{C}-8), 120.8$ (C-7), 118.2 (C-5), $109.6(\mathrm{C}-9 \mathrm{a}), 72.4\left(\mathrm{OCH}_{2}\right), 56.6\left(\mathrm{OCH}_{3}\right), 47.7\left(\mathrm{C}-1^{\prime}\right), 22.1\left(\mathrm{C}-2^{\prime}\right)$ (Figure S6, Supplementary Data). HRMS (ESI+): $m / z\left[\mathrm{C}_{24} \mathrm{H}_{21} \mathrm{NO}_{5}+\mathrm{H}\right]+$ calcd. for $\left[\mathrm{C}_{24} \mathrm{H}_{22} \mathrm{NO}_{5}\right]$ : 404.14980; found 404.14816 (Figure S7, Supplementary Data).

\subsubsection{Synthesis of 4-(2-Hydroxyethoxy)-3-methoxy-9H-xanthen-9-one (12)}

Starting from compound 2, compound 12 was synthesized through an adaptation of a protocol previously described for Williamson ether synthesis [62]. Compound 2 $(0.23 \mathrm{~g}, 0.95 \mathrm{mmol})$ was dissolved in anhydrous acetone, and $\mathrm{NaH}(0.10 \mathrm{~g}, 4.17 \mathrm{mmol})$ and $\mathrm{BrCH}_{2} \mathrm{CH}_{2} \mathrm{OH}(0.30 \mathrm{~mL}, 4.23 \mathrm{mmol})$ were added. The mixture was kept under reflux and magnetic stirring for $24 \mathrm{~h}$. Then, the organic solvent was evaporated under reduced pressure, and the crude product was dissolved in ethyl acetate. This solution was washed with a $0.5 \mathrm{M} \mathrm{NaOH}$ solution $(3 \times 100 \mathrm{~mL})$ and $\mathrm{H}_{2} \mathrm{O}(2 \times 50 \mathrm{~mL})$. The organic layer was dried with anhydrous $\mathrm{NaSO}_{4}$, filtered, and the organic solvent was evaporated under reduced pressure affording a yellow solid.

Yield: $80 \%$. m.p.: $137-140{ }^{\circ} \mathrm{C}$. IR $v_{\max }\left(\mathrm{cm}^{-1}\right)(\mathrm{KBr}): 3423.2,1602.0,1467.0,1290.5$, 1224.5, 1068.1, 905.5, 823.5, 760.4. ${ }^{1} \mathrm{H}$ NMR (300.13 $\left.\mathrm{MHz} \mathrm{CDCl}_{3}\right) \delta: 8.33$ (dd, $J=6.0,1.3$ $\mathrm{Hz}, 1 \mathrm{H}, \mathrm{H}-8), 8.12$ (d, $J=6.8 \mathrm{~Hz}, 1 \mathrm{H}, \mathrm{H}-1), 7.84(\mathrm{~m}, 1 \mathrm{H}, \mathrm{H}-6), 7.53$ (dd, $J=6.3,0.9 \mathrm{~Hz}, 1 \mathrm{H}$, H-5), 7.39 (ddd, $J=6.0,5.3,0.8 \mathrm{~Hz}, 1 \mathrm{H}, \mathrm{H}-7), 7.03$ (d, $J=6.8 \mathrm{~Hz}, 1 \mathrm{H}, \mathrm{H}-2), 4.33$ (t, $J=3.3$ $\left.\mathrm{Hz}, 2 \mathrm{H}, \mathrm{OCH}_{2}\right), 4.05(\mathrm{~s}, 1 \mathrm{H}, \mathrm{OH}), 4.03\left(\mathrm{~s}, 3 \mathrm{H}, \mathrm{OCH}_{3}\right), 3.90\left(\mathrm{t}, \mathrm{J}=3.5 \mathrm{~Hz}, 2 \mathrm{H}, \mathrm{CH}_{2} \mathrm{OH}\right) .{ }^{13} \mathrm{C}$

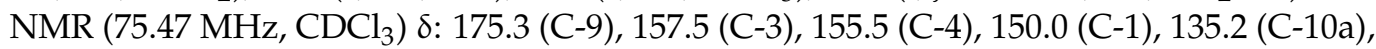
135.1 (C-4a), 125.8 (C-2), 124.2 (C-6), 121.4 (C-8), 120.8 (C-7), 118.2 (C-5), 115.9 (C-8a), 109.7 (C-9a), $75.1\left(\mathrm{OCH}_{2}\right), 60.4\left(\mathrm{CH}_{2} \mathrm{OH}\right), 56.5\left(\mathrm{OCH}_{3}\right)$ (Figure S8, Supplementary Data). HRMS (ESI+): $m / z\left[\mathrm{C}_{16} \mathrm{H}_{14} \mathrm{O}_{5}+\mathrm{H}\right]+$ calcd. for $\left[\mathrm{C}_{16} \mathrm{H}_{15} \mathrm{O}_{5}\right]$ : 287.09195; found 287.09042 (Figure S9, Supplementary Data).

3.1.5. Synthesis of $(S)-2-\{[9-0 x o-7-((1-P h e n y l e t h y l)$ carbamoyl)-9H-xanthen-3-yl]oxy\}acetate $[(S)-16]$ and of $(R)-2-\{[9-$ oxo-7-((1-Phenylethyl)carbamoyl)-9H-xanthen-3-yl]oxy\}acetate [(R)-16]

Starting from compound $(S)-\mathbf{1 5}$ or $(R)-15$, a reaction was carried out under anhydrous conditions and nitrogen atmosphere according to the described procedure [63] to afford an orange oil. Then, the synthesis of compounds $(S)-16$ and $(R)-16$ was carried out using the same method as described, previously, for 2'-[(9-oxo-9H-xanthene-3,4diyl)bis(oxy)]diacetate (6), adjusting the amount of $\mathrm{K}_{2} \mathrm{CO}_{3}$ and $\mathrm{BrCH}_{2} \mathrm{COOCH}_{3}$ according to the number of hydroxyl groups of the chemical substrate and the stoichiometry of the reaction [62], affording $(S)-16$ and $(R)-16$ as white solid.

(S)-2-\{[9-oxo-7-((1-Phenylethyl)carbamoyl)-9H-xanthen-3-yl]oxy\}acetate [(S)-16]: Yield: $80 \%$. m.p.: $>330{ }^{\circ} \mathrm{C}$. $[\alpha]_{\mathrm{D}}{ }^{25^{\circ} \mathrm{C}}+686.0\left(c=0.86 \times 10^{-3} \mathrm{gmL}^{-1}\right.$ in $\left.\mathrm{CH}_{3} \mathrm{OH}\right)$. e.r: $>99 \%(\mathrm{k}$ : 1.63) (Figure 1).

(R)-2-\{[9-oxo-7-((1-Phenylethyl)carbamoyl)-9H-xanthen-3-yl]oxy\}acetate [(R)-16]: Yield: $75 \%$. m.p.: $>330^{\circ} \mathrm{C}$. $[\alpha]_{\mathrm{D}}{ }^{25^{\circ} \mathrm{C}}-686.0\left(\mathrm{c}=0.86 \times 10^{-3} \mathrm{gmL}^{-1}\right.$ in $\left.\mathrm{CH}_{3} \mathrm{OH}\right)$. e.r: $>99 \%(\mathrm{k}$ : 0.52) (Figure 1).

IR $v_{\max }\left(\mathrm{cm}^{-1}\right)(\mathrm{KBr}): 3431.7,3295.6,1759.3,1648.4,1617.9,1540.7,1479.7,1348.7$, 1213.5, 1067.7, 828.6, 781.6. ${ }^{1} \mathrm{H}$ NMR (300.13 MHz, DMSO- $\left.d_{6}\right) \delta: 9.20$ (d, $J=7.8 \mathrm{~Hz}, 1 \mathrm{H}$, CONH), $8.76(\mathrm{~d}, J=2.3 \mathrm{~Hz}, 1 \mathrm{H}, \mathrm{H}-1), 8.33(\mathrm{dd}, J=8.8,2.3 \mathrm{~Hz}, 1 \mathrm{H}, \mathrm{H}-3), 8.15$ (d, J = 8.9 Hz, $1 \mathrm{H}, \mathrm{H}-8), 7.71$ (d, J = 8.8 Hz, 1H, H-4), 7.45-7.26 (d,t,d, J = 7.5 Hz, 5H, H-1" to H-6"), 7.23 (d, $J=2.4 \mathrm{~Hz}, 1 \mathrm{H}, \mathrm{H}-5), 5.21\left(\mathrm{~m}, 1 \mathrm{H}, \mathrm{H}-1^{\prime}\right), 5.07\left(\mathrm{~s}, 2 \mathrm{H}, \mathrm{OCH}_{2}\right), 3.74\left(\mathrm{~s}, 3 \mathrm{H}, \mathrm{COOCH}_{3}\right), 1.52(\mathrm{~d}, J$ $\left.=7.8 \mathrm{~Hz}, 3 \mathrm{H}, \mathrm{H}-2^{\prime}\right) .{ }^{13} \mathrm{C} \mathrm{NMR}\left(75.47 \mathrm{MHz}, \mathrm{DMSO}-d_{6}\right) \delta: 174.9$ (C-9), $168.6(\mathrm{CONH}), 164.1$ 
$\left(\mathrm{COOCH}_{3}\right), 163.4$ (C-6), 157.3 (C-10a), 157.2 (C-4a), 144.8 (C-1"), 134.1 (C-3), $130.4(\mathrm{C}-2)$, 128.3 (C-3" to C-5"), 126.7 (C-8), 126.1 (C-2" and C-6"), 125.5 (C-1), 118.2 (C-8a), 114.1 (C-7), $101.8(\mathrm{C}-5), 65.1\left(\mathrm{OCH}_{2}\right), 52.1\left(\mathrm{OCH}_{3}\right), 48.7\left(\mathrm{C}-1^{\prime}\right), 22.2\left(\mathrm{C}-2^{\prime}\right)$ (Figure S10, Supplementary Data). HRMS (ESI+): $m / z\left[\mathrm{C}_{24} \mathrm{H}_{19} \mathrm{NO}_{6}+\mathrm{H}\right]+$ calcd. for $\left[\mathrm{C}_{24} \mathrm{H}_{20} \mathrm{NO}_{6}\right]: 432.14471$; found 432.14410 (Figure S11, Supplementary Data).

3.1.6. Synthesis of (S)-2-\{[9-oxo-7-((1-Phenylethyl)carbamoyl)-9H-xanthen-3-yl]oxy\}acetic Acid [(S)-17] and of (R)-2-\{[9-oxo-7-((1-Phenylethyl)carbamoyl)-9H-xanthen-3-yl]oxy\}acetic Acid [(R)-17]

The esters $(S)-16$ and $(R)-16$ were hydrolysed to the acetic acid derivatives $(S)-17$ and $(R)-17$ through the method previously described for compound 7 [62], furnishing a white solid.

(S)-2-\{[9-oxo-7-((1-phenylethyl)carbamoyl)-9H-xanthen-3-yl]oxy\}acetic acid [(S)-17]: Yield: $51 \%$. m.p.: $>330^{\circ} \mathrm{C}$. $[\alpha]_{\mathrm{D}}{ }^{25^{\circ} \mathrm{C}}+450.0\left(c=0.75 \times 10^{-3} \mathrm{gmL}^{-1}\right.$ in $\left.\mathrm{CH}_{3} \mathrm{OH}\right)$. e.r: $>98 \%$ (k: 0.56) (Figure S12, Supplementary Data).

(R)-2-\{[9-oxo-7-((1-phenylethyl)carbamoyl)-9H-xanthen-3-yl]oxy\}acetic acid [(R)-17]: Yield: $71 \%$. m.p.: $>330^{\circ} \mathrm{C}$. $[\alpha]_{\mathrm{D}}{ }^{25^{\circ} \mathrm{C}}-450.0\left(c=0.75 \times 10^{-3} \mathrm{gmL}^{-1}\right.$ in $\left.\mathrm{CH}_{3} \mathrm{OH}\right)$. e.r: $>$ 99\% (k: 0.38) (Figure S12, Supplementary Data).

IR $v_{\max }\left(\mathrm{cm}^{-1}\right)(\mathrm{KBr}): 3306.9,3082.7,2977.7,1718.6,1664.0,1619.8,1552.4,1480.6$, 1236.6, 1065.8, 830.9, 779.2. ${ }^{1} \mathrm{H}$ NMR (300.13 MHz, DMSO- $\left.d_{6}\right) \delta: 9.19(\mathrm{~d}, J=7.9 \mathrm{~Hz}, 1 \mathrm{H}$, CONH), $8.74(\mathrm{~d}, J=2.3 \mathrm{~Hz}, 1 \mathrm{H}, \mathrm{H}-1), 8.31(\mathrm{dd}, J=8.8,2.3 \mathrm{~Hz}, 1 \mathrm{H}, \mathrm{H}-3), 8.14(\mathrm{~d}, J=9.0 \mathrm{~Hz}$, $1 \mathrm{H}, \mathrm{H}-8), 7.72(\mathrm{~d}, \mathrm{~J}=8.8 \mathrm{~Hz}, 1 \mathrm{H}, \mathrm{H}-4), 7.44-7.24\left(\mathrm{~d}, \mathrm{t}, \mathrm{d}, \mathrm{J}=7.5 \mathrm{~Hz}, 5 \mathrm{H}, \mathrm{H}-\mathrm{1}^{\prime \prime}\right.$ to $\left.\mathrm{H}-6^{\prime \prime}\right), 7.17$ $(\mathrm{d}, J=2.1 \mathrm{~Hz}, 1 \mathrm{H}, \mathrm{H}-5), 7.12(\mathrm{dd}, J=9.0,2.1 \mathrm{~Hz}, 1 \mathrm{H}, \mathrm{H}-7), 5.21\left(\mathrm{~m}, 1 \mathrm{H}, \mathrm{H}-1^{\prime}\right), 4.94(\mathrm{~s}, 2 \mathrm{H}$, $\left.\mathrm{OCH}_{2}\right), 1.52\left(\mathrm{~d}, J=7.9 \mathrm{~Hz}, 3 \mathrm{H}, \mathrm{H}-2^{\prime}\right) .{ }^{13} \mathrm{C}$ NMR (75.47 MHz, DMSO-d 6 ) $\delta: 174.8(\mathrm{C}-9), 165.4$ (CONH), 164.1 (COOH), 163.6 (C-6), 157.3 (C-10a), 157.2 (C-4a), 144.8 (C-1"), $134.0(\mathrm{C}-3)$, 130.3 (C-2), 128.2 (C-3" to C-5"), 126.6 (C-8), 126.1 (C-2" and C-6"), 125.4 (C-1), 118.1 (C-8a), 114.0 (C-7), $101.6(\mathrm{C}-5), 65.0\left(\mathrm{OCH}_{2}\right), 48.7\left(\mathrm{C}-1^{\prime}\right), 22.1\left(\mathrm{C}-2^{\prime}\right)$ (Figure S13, Supplementary Data). HRMS (ESI+): $m / z\left[\mathrm{C}_{24} \mathrm{H}_{19} \mathrm{NO}_{6}+\mathrm{H}\right]+$ calcd. for $\left[\mathrm{C}_{24} \mathrm{H}_{20} \mathrm{NO}_{6}\right]: 418.12906$; found 418.12802 (Figure S14, Supplementary Data).

3.1.7. Synthesis of 6-\{2-[((R)-2-Hydroxy-1-phenylethyl)amino]-2-oxoethoxy\}-9-oxo- $N-[(S)-1$ phenylethyl]-9H-xanthene-2-carboxamide $[(R, S)-18]$ and of 6-\{2-[((S)-2-Hydroxy-1-phenylethyl)amino]-2-oxoethoxy\}-9-oxo- $N-[(R)-1$-phenylethyl]$9 H$-xanthene-2-carboxamide $[(S, R)-18]$

Compounds $(\boldsymbol{R}, S)-\mathbf{1 8}$ and $(S, R)-\mathbf{1 8}$ were synthetized according to the method previously described for compound 8 [62], being obtained as white solid, using the enantiomers $(S)-(+)-2$-phenylglycinol and $(R)-(-)-2$-phenylglycinol, respectively.

6-\{2-[((R)-2-Hydroxy-1-phenylethyl)amino]-2-oxoethoxy\}-9-oxo- $N$-[(S)-1-phenylethyl]$9 H$-xanthene-2-carboxamide $[(\boldsymbol{R}, S)-22]:$ Yield: $65 \%$. m.p.: $>330{ }^{\circ} \mathrm{C} .[\alpha]_{\mathrm{D}}{ }^{2{ }^{\circ} \mathrm{C}}-211.3(c=$ $0.71 \times 10^{-3} \mathrm{gmL}^{-1}$ in $\left.\mathrm{CH}_{3} \mathrm{OH}\right)$. e.r: $>99 \%$ (k: 2.58) (Figure S15, Supplementary Data).

6-\{2-[((S)-2-Hydroxy-1-phenylethyl)amino]-2-oxoethoxy\}-9-oxo- $N$-[(R)-1-phenylethyl]$9 H$-xanthene-2-carboxamide $[(S, R)-22]:$ Yield: $63 \%$. m.p.: $>330{ }^{\circ} \mathrm{C} .[\alpha]_{\mathrm{D}}{ }^{25^{\circ} \mathrm{C}}+211.0(c=$ $0.71 \times 10^{-3} \mathrm{gmL}^{-1}$ in $\left.\mathrm{CH}_{3} \mathrm{OH}\right)$. e.r: $>99 \%$ (k: 0.47) (Figure S15, Supplementary Data).

IR $v_{\max }\left(\mathrm{cm}^{-1}\right)(\mathrm{KBr}): 3261.5,1654.3,1616.5,1471.4,1222.4,1140.4,1060.4,911.8,763.0$. ${ }^{1} \mathrm{H}$ NMR $\left(300.13 \mathrm{MHz}, \mathrm{DMSO}-d_{6}\right) \delta: 9.21\left(\mathrm{~d}, J=8.1 \mathrm{~Hz}, 1 \mathrm{H}, \mathrm{CONHC}-1^{\prime}\right), 8.78(\mathrm{~d}, J=2.4 \mathrm{~Hz}$, $1 \mathrm{H}, \mathrm{H}-1), 8.68\left(\mathrm{~d}, J=8.1 \mathrm{~Hz}, 1 \mathrm{H}, \mathrm{CONHC}-1^{\prime \prime \prime}\right), 8.33(\mathrm{dd}, J=9.0,2.4 \mathrm{~Hz}, 1 \mathrm{H}, \mathrm{H}-3), 8.15(\mathrm{~d}, J$ $=9.0 \mathrm{~Hz}, 1 \mathrm{H}, \mathrm{H}-8), 7.72(\mathrm{~d}, J=9.0 \mathrm{~Hz}, 1 \mathrm{H}, \mathrm{H}-4), 7.46-7.26\left(\mathrm{~d}, \mathrm{t}, \mathrm{d}, J=7.5 \mathrm{~Hz}, 10 \mathrm{H}, \mathrm{H}-1^{\prime \prime}\right.$ to H-6" and $\mathrm{H}-1^{\prime \prime \prime \prime}$ to $\mathrm{H}-6^{\prime \prime \prime \prime \prime}, 7.23(\mathrm{~d}, J=2.5 \mathrm{~Hz}, 1 \mathrm{H}, \mathrm{H}-5), 7.13(\mathrm{dd}, J=9.0,2.5 \mathrm{~Hz}, 1 \mathrm{H}, \mathrm{H}-7)$, $5.22\left(\mathrm{~m}, 1 \mathrm{H}, \mathrm{H}-1^{\prime}\right), 5.05(\mathrm{~s}, 1 \mathrm{H}, \mathrm{OH}), 4.92\left(\mathrm{~m}, 1 \mathrm{H}, \mathrm{H}-1^{\prime \prime \prime}\right), 4.82\left(\mathrm{~s}, 2 \mathrm{H}, \mathrm{OCH}_{2}\right), 3.61(\mathrm{~m}, 2 \mathrm{H}$, $\left.\mathrm{CH}_{2} \mathrm{OH}\right), 1.52\left(\mathrm{~d}, J=8.1 \mathrm{~Hz}, 3 \mathrm{H}, \mathrm{H}-2^{\prime}\right) .{ }^{13} \mathrm{C} \mathrm{NMR}\left(75.47 \mathrm{MHz}, \mathrm{DMSO}-d_{6}\right) \delta: 174.8(\mathrm{C}-9)$, $166.5\left(\mathrm{CONHC}-1^{\prime}\right), 164.1\left(\mathrm{CONHC}^{\prime}{ }^{\prime}\right), 163.7$ (C-6), $157.2(\mathrm{C}-10 \mathrm{a}), 157.1(\mathrm{C}-4 \mathrm{a}), 144.8\left(\mathrm{C}-1^{\prime \prime}\right)$, $140.8\left(\mathrm{C}-1^{\prime \prime \prime \prime}\right), 134.1(\mathrm{C}-3), 130.4(\mathrm{C}-2), 128.3\left(\mathrm{C}-3^{\prime \prime}\right.$ to $\left.\mathrm{C}-5^{\prime \prime}\right), 128.1\left(\mathrm{C}-1^{\prime \prime \prime}\right), 126.9\left(\mathrm{C}-3^{\prime \prime \prime \prime}\right.$ to $\left.\mathrm{C}-5^{\prime \prime \prime \prime}\right), 126.6(\mathrm{C}-8), 126.1\left(\mathrm{C}-2^{\prime \prime}, \mathrm{C}-6^{\prime \prime}, \mathrm{C}-2^{\prime \prime \prime \prime}\right.$ and $\left.\mathrm{C}-6^{\prime \prime \prime \prime}\right), 125.4(\mathrm{C}-1), 118.2(\mathrm{C}-8 \mathrm{a}), 115.3$ (C-4), $114.5(\mathrm{C}-7), 101.7(\mathrm{C}-6), 64.4\left(\mathrm{OCH}_{2}\right), 55.0\left(\mathrm{CH}_{2} \mathrm{OH}\right), 48.7\left(\mathrm{C}-1^{\prime}\right), 22.2\left(\mathrm{C}-2^{\prime}\right)$ (Figure 
S16, Supplementary Data). HRMS (ESI+): $m / z$ [HRMS (ESI+): $m / z\left[\mathrm{C}_{32} \mathrm{H}_{28} \mathrm{~N}_{2} \mathrm{O}_{6}+\mathrm{H}\right]+$ calcd. for $\left[\mathrm{C}_{32} \mathrm{H}_{29} \mathrm{~N}_{2} \mathrm{O}_{6}\right]$ : 537.20256; found 537.20142 (Figure S17, Supplementary Data).

\subsection{Chiral Liquid Chromatography}

The cLC analyses of the enantiomeric purity were performed on a Jasco model 880-PU Intelligent HPLC pump (JASCO Corporation, Tokyo, Japan), equipped with a JASCO model 880-30 solvent mixer involving an 875-UV intelligent UV-vis detector and a 7125 injector (Rheodyne LCC., Rohnert Park, California) fitted with a $20 \mu \mathrm{L}$ loop. The data were handled on ChromNAV Chromatography Data System (version 1.19.1) from JASCO Corporation (Tokyo, Japan). The chromatographic column used was $(S, S)-W h e l k-O 1^{\circledR}$ ( $25 \mathrm{~cm} \times 4.6 \mathrm{~mm}$ i.d., $5 \mu \mathrm{m}$ particle size, $100-\AA ̊$ pore size) from Regis Technologies, Inc. (Morton Grove, IL, USA. The mobile phase was degassed in an ultrasonic bath for 15 min after preparation in a volume/volume ratio. Analyses were performed at $25 \pm 2{ }^{\circ} \mathrm{C}$ in isocratic mode. The flow rate used was $0.5 \mathrm{~mL} / \mathrm{min}$, and the working pressure was between 30 and 35 bar. The chromatograms were monitored by UV at a wavelength of $254 \mathrm{~nm}$. The sample injections $(10 \mu \mathrm{L})$ were carried out in triplicate. The column void time $\left(\mathrm{t}_{0}\right)$ was considered to be equal to the peak of the solvent front and was taken from each particular run. The e.r. was determined by the relative percentages of the peak areas according to e.r. $(\%)=100 \times([R] /([R]+[S])$ or $100 \times([S] /([S]+[R])$, where $[S]$ and $[R]$ are the area of the peak of each enantiomer [64].

\subsection{Docking Studies}

The crystal structures of the AcrB (PDB: 4DX5) [54], AcrA (PDB: 2F1M) [65], and TolC (PDB: 1EK9) [66] portions of the AcrAB-TolC bacterial efflux system, downloaded from the protein databank (PDB) [67], were used for this study. The structures of the known AcrAB-TolC inhibitors D13-9001, doxorubicin, MBX-3132, minocycline, and phenyl-arginyl$\beta$-naphthylamide, along with the structures of the tested compounds were drawn with ChemDraw (PerkinElmer Informatics, MA, USA) and minimized using ArgusLab. Docking was carried out using AutoDock Vina (Scripps, La Jolla, CA, USA) [68] in the sites described in $[47,48]$. Since the crystal structure of NorA efflux pump is not available, a homology model was prepared. The model was generated using the Swiss Model server [69] and the sequence was deposited in Uniprot (Q5HHX4) [70], using the EmrD pump from Escherichia coli (PDB: 2GFP) as the homolog, as described previously [49]. The top 9 poses were collected for each molecule, and the lowest docking score value was associated with the most favorable binding conformation. PyMol (Schrödinger, New York, NY, USA) was used for molecular visualization [71].

\subsection{Microorganisms}

As Gram-positive strains, Staphylococcus aureus American Type Culture Collection (ATCC) 25923, Enterococcus faecalis ATCC 29212 and methicillin and ofloxacin-resistant Staphylococcus aureus 272123 clinical isolate were used. As Gram-negative strains, Escherichia coli ATCC 25922, Pseudomonas aeruginosa ATCC 27853, the acrA gene inactivated mutant Salmonella enterica serovar Typhimurium SL1344 (SE03), and clinical isolates of the extendedspectrum $\beta$-lactamase producer (ESBL) E. coli SA/ 2 were investigated in this study.

The bacteria used for the QS assay were Chromobacterium violaceum wild type 85 (wt85), capable of producing violacein, a purple pigment, mediated by AHL signal molecule, capable of endogenous QS-signal molecule production ( $N$-hexanoyl-L-HSL), the Tn5 transposase-mutant $C$. violaceum CV026 (CV026), capable of producing violacein in the presence of AHL, but incapable of producing endogenous QS-signal molecules, serving as a detector of external stimuli provided by Sphingomonas paucimobilis Ezf 10-17 (EZF), a AHL-producing-strain, and Serratia marcescens AS-1, a producer of prodigiosin (2-methyl3-pentyl-6-methoxyprodigiosin), an orange-red pigment mediated by the AHL-signal molecules, capable of endogenous QS-signal molecule production ( $N$-hexanoyl-L-HSL). These bacteria are Gram-negative [60]. 
As yeast Candida albicans ATCC 10231, and as filamentous fungi Aspergillus fumigatus ATCC 204305 and a dermatophyte (Trichophyton rubrum FF5, clinical isolate) were used. Cultures were obtained in SDA.

\subsection{Antibacterial Assay and Synergy with Antimicrobials}

The antibacterial activity was assessed by determination of the MIC of the compounds using the microdilution method, in a 96-well plate, according to the Clinical and Laboratory Standard Institute (CLSI) guidelines [72]. The media used was MHB II. The concentrations tested ranged from $64 \mu \mathrm{g} / \mathrm{mL}$ to $4 \mu \mathrm{g} / \mathrm{mL}$, which were later converted to $\mu \mathrm{M}$. The MIC was determined by visual inspection. DMSO, in subinhibitory concentrations $(1 \% v / v)$, was used as a solvent for the compounds.

The combined effect of the compounds and clinically relevant antimicrobial drugs was evaluated by determining the antibiotic MIC in the presence of each compound. Briefly, the MIC of cefotaxime (CTX) (Duchefa Biochemie, Haarlem, The Netherlands) was determined in the presence of the highest concentration of each compound tested that did not affect bacterial growth of $E$. coli SA/2 when the compound was used alone. The antibiotic tested was serially diluted, whereas the concentration of each compound was kept fixed at $64 \mu \mathrm{g} / \mathrm{mL}$, which were later converted to $\mu \mathrm{M}$. Antibiotic MICs were determined as described above.

\subsection{Antifungal Assay}

The susceptibility tests for yeasts were performed based on the Clinical and Laboratory Standards Institute (CLSI) description for the broth microdilution method on the reference document M27A-3 for yeasts [73] and M38-A2 [74] for filamentous fungi, in RPMI-1640 broth culture media. The concentrations tested ranged from $128 \mu \mathrm{g} / \mathrm{mL}$ to $32 \mu \mathrm{g} / \mathrm{mL}$. The MIC was considered the lowest concentration that was able to totally inhibit the growth when comparing to control (non-treated microorganism in culture medium). A DMSO control (microorganism in RPMI with DMSO (1\% v/v) was included.

\subsection{Efflux Pump Inhibition Assay}

The efflux pump inhibition assay was carried out using compounds 5-7, 9, 10, 12, and the enantiomeric pairs 11, 17, and 18, and this effect was studied in the strains SE03 and $S$. aureus 272123. The intracellular accumulation of EB, a known substrate of bacteria efflux pumps, was monitored through real-time fluorimetry. The method used was automated, using a CLARIOstar Plus plate reader (BMG Labtech, Ortenberg, Germany). The positive controls were reserpine and $\mathrm{CCCP}$, and were applied at the non-toxic concentration of $25 \mu \mathrm{M}$, as well as DMSO, used as solvent, which was applied at $1 \%$ v/v. S. aureus 272123 and SE03 were incubated in TSB and LB-B, respectively, at $37^{\circ} \mathrm{C}$ until they reached an optical density $(\mathrm{OD})=0.4-0.6$ at $\lambda=600 \mathrm{~nm}$. The culture was centrifuged at $13,000 \times g$ for $3 \mathrm{~min}$, and the pellet was washed and resuspended with PBS. The suspension was centrifuged again in the same conditions and resuspended in PBS. The compounds were diluted to $50 \mu \mathrm{M}$ in a solution $1 \mu \mathrm{g} / \mathrm{mL}$ of $\mathrm{EB}$, and $50 \mu \mathrm{L}$ of this solution were transferred into a 96-well black microtiter plate (Greiner Bio-One Hungary Kft, Mosonmagyaróvár, Fertósor, Hungary). Then, $50 \mu \mathrm{L}$ of bacterial suspension $\left(\mathrm{OD}_{600}=0.4-0.6\right)$ were added to each well. The plates were placed into the CLARIOstar plate reader, and the fluorescence was monitored at excitation $(530 \mathrm{~nm})$ and emission $(600 \mathrm{~nm})$ wavelengths every minute for $1 \mathrm{~h}$ on a real-time basis. From the real-time data, the activity of the compounds was expressed as the RFI of the last time point (minute 60) of the EB accumulation assay, which was calculated according to the following formula:

$$
\mathrm{RFI}=\frac{\mathrm{RF}_{\text {treated }}-\mathrm{RF}_{\text {untreated }}}{\mathrm{RF}_{\text {untreated }}}
$$

where $\mathrm{RF}_{\text {treated }}$ is the relative fluorescence $(\mathrm{RF})$ at the last time point of $\mathrm{EB}$ accumulation curve in the presence of the compound, and $\mathrm{RF}_{\text {untreated }}$ is the $\mathrm{RF}$ at the last time point of the EB accumulation curve of the untreated control, having only the solvent (DMSO) control. 


\subsection{Inhibition of Biofilm Formation}

The enantiomeric pair composed by compounds $(S, S)-8$ and $(R, R)-8$, compound $(R)-17$ and $(R, S)-18$ were tested for their ability to inhibit the formation of biofilm. The bacterial strains used were the Gram-positive S. aureus ATCC 25923 and S. aureus 272123. The detection of the biofilm formation was possible with the use of the dye crystal violet $(\mathrm{CV}$; $0.1 \% v / v)$. The initial inoculum was incubated in TSB overnight, and then diluted to an $\mathrm{OD}_{600}$ of 0.1 . Then, the bacterial suspension was added to 96-well microtiter plates and the compounds were added at a concentration of $\frac{1}{2}$ MIC, and for compounds whose MIC was higher than $100 \mu \mathrm{M}$, a concentration of $100 \mu \mathrm{M}$ was used. The final volume in each well was $200 \mu \mathrm{L}$. Reserpine was used as the positive control, as it was the same compound used in the efflux pump inhibition assay and it has shown activity in the inhibition of biofilm formation in S. aureus strains [58]. The plates were incubated at $30^{\circ} \mathrm{C}$ for $48 \mathrm{~h}$, with gentle stirring (100 rpm). After this incubation period, the TSB medium was discarded, and the plates were washed with tap water to remove unattached cells. Afterwards, $200 \mu \mathrm{L}$ of a $0.1 \% v / v$ CV solution were added to the wells and incubated for $15 \mathrm{~min}$ at room temperature. Then, the CV solution was removed from the wells, and the plates were washed again with tap water, and $200 \mu \mathrm{L}$ of a $70 \%$ ethanolic solution were added to the wells. The biofilm formation was determined by measuring the $\mathrm{OD}_{600}$ using a Multiscan EX ELISA plate reader (Thermo Labsystems, Cheshire, WA, USA). The anti-biofilm effect of the compounds was expressed as the percentage (\%) of a decrease in biofilm formation.

\subsection{Quorum-Sensing Assay}

The QS inhibitory effect of the compounds was examined on the EZF and the sensor CV026 strains, on the wt85 strain, and on $S$. marcescens, for $(S, S)-8,(R, R)-8,(R)-\mathbf{1 7}$, and $(R, S)-18$. The method used was the parallel inoculation method, where pair combinations of the used sensor strain CV026 and the EZF, the AHL-producing strain, were inoculated directly onto the $\mathrm{LB}^{*}$-A agar surface in parallel, at an approximate distance of $5 \mathrm{~mm}$ from each other. S. marcescens AS- 1 and wt 85 were inoculated as a single line. Filter paper disks (7 $\mathrm{mm}$ in diameter) were placed on the center of the inoculated line(s) and impregnated with $8 \mu \mathrm{L}$ of a solution of $10 \mathrm{mM}$ of the compounds. PMZ, previously described as a QS inhibitor, was used as the positive control [59]. The agar plates were incubated at room temperature $\left(20^{\circ} \mathrm{C}\right)$ for $24-48 \mathrm{~h}$. The $\mathrm{QS}$ inhibition was accessed visually through the inhibition of pigment production. The discolored but intact bacterial colonies were measured with a ruler $[59,60,75]$.

\section{Conclusions}

In this study, a small library of chiral derivatives of xanthones was synthesized, having as chemical model molecules of antimicrobial peptides. Herein, not only the potential of these derivatives as antimicrobial agents were studied but also their usefulness as antimicrobial helpers, capable of acting in resistance mechanisms and possibly as combination therapy with antimicrobials.

Concerning the antimicrobial activity, none of the derivatives tested displayed activity against the bacterial and fungal strains tested. However, when it comes to synergy with antibiotics, it was observed that compounds 6 and (S)-11 were able to decrease the MIC of a $\beta$-lactam antibiotic in an ESBL-producing strain of E. coli, suggesting the potential of these compounds to also evade resistance mechanisms. It should also be highlighted that, although the correspondent enantiomer was also tested, they were not active in the same way, which leads to the conclusion that enantioselectivity plays an important role in these compounds.

Some chiral derivatives and their precursors were also tested for their potential as inhibitors of efflux pumps. Herein, it was shown that one compound, $(\boldsymbol{R}, \boldsymbol{R})-\mathbf{8}$, was active as an inhibitor of efflux pumps in the Gram-positive strain tested, whereas three compounds, $(S, S)-8,(R)-17$, and $(R, S)-18$ had the same effect in the Gram-negative strain tested. Once again, there was enantioselectivity for this activity in different strains. Moreover, both 
enantiomers of 8 could be investigated as antimicrobial adjuvants in infections where Gram-positive and Gram-negative multidrug-resistant bacteria were present.

The compounds were also investigated for their ability to inhibit mechanisms related to efflux pumps, such as biofilm formation and QS. It was shown that none of the compounds presented higher inhibition of biofilm formation than reserpine, used as a positive control, but compound $(R, R)-8$ showed the highest inhibition, which may suggest a link between inhibition of efflux pumps and biofilm formation, in this case. The enantiomeric pair composed by compounds $(S, S)-8$ and $(R, R)-8$ also proved successful in inhibiting QS in the tested strains. These results suggest that, in the case of QS, enantioselectivity does not play an important role, rather than the nature of the substituents.

In conclusion, it can be observed that these compounds show potential for the activities tested. Future studies will focus on the evaluation of the cytotoxicity of the compounds in eukaryotic cells and in deeper studies of their mechanisms of efflux pump inhibition. Docking studies presented suggest that these compounds can interact with the most relevant efflux pumps, but other mechanisms, such as membrane disturbance, which is characteristic of antimicrobial peptides, could also play a role in the obtained results.

Supplementary Materials: The following are available online at https:/ /www.mdpi.com/article/ $10.3390 / \mathrm{ph} 14111141 / \mathrm{s} 1$, Table S1: Minimum inhibitory concentrations of the compounds in the antibacterial and antifungal activity assays and synergy with antibiotics; Figure S1. ${ }^{1} \mathrm{H}$ NMR $(300.13$ $\mathrm{MHz}$, DMSO-d6) and ${ }^{13} \mathrm{C}$ NMR (75.48 MHz, DMSO- $d 6$ ) for compound 9; Figure S2. Electrospray ESI data for compound 9; Figure S3. ${ }^{1} \mathrm{H}$ NMR $\left(300.13 \mathrm{MHz}\right.$, DMSO-d6) and ${ }^{13} \mathrm{C}$ NMR (75.48 $\mathrm{MHz}$, DMSO-d6) for compound 10; Figure S4. Electrospray ESI data for compound 10; Figure S5. Chromatograms for the enantioseparation of the enantiomeric pair 11, at optimized chromatographic conditions; Figure S6. ${ }^{1} \mathrm{H}$ NMR (300.13 MHz, DMSO- $\left.d 6\right)$ and ${ }^{13} \mathrm{C}$ NMR (75.48 MHz, DMSO-d6) for the enantiomeric pair 11; Figure S7. Electrospray ESI data for enantiomeric pair 11; Figure S8. ${ }^{1} \mathrm{H}$ NMR (300.13 MHz, $\mathrm{CDCl}_{3}$ ) and ${ }^{13} \mathrm{C}$ NMR (75.48 MHz, DMSO- $\left.d 6\right)$ for compound 12; Figure S9. Electrospray ESI data for compound 12; Figure S10. ${ }^{1} \mathrm{H}$ NMR $\left(300.13 \mathrm{MHz}\right.$, DMSO-d6) and ${ }^{13} \mathrm{C}$ NMR (75.48 MHz, DMSO- $d 6$ ) for the enantiomeric pair 16; Figure S11. Electrospray ESI data for enantiomeric pair 16; Figure S12. Chromatograms for the enantioseparation of the enantiomeric pair 16, at optimized chromatographic conditions; Figure S13. ${ }^{1} \mathrm{H}$ NMR $(300.13 \mathrm{MHz}$, DMSO-d6) and ${ }^{13} \mathrm{C}$ NMR $(75.48 \mathrm{MHz}$, DMSO-d6) for the enantiomeric pair 17; Figure S14. Electrospray ESI data for enantiomeric pair 17; Figure S15. Chromatograms for the enantioseparation of the enantiomeric pair 18, at optimized chromatographic conditions; Figure S16. ${ }^{1} \mathrm{H}$ NMR (300.13 MHz, DMSO-d6) and ${ }^{13} \mathrm{C}$ NMR $(75.48 \mathrm{MHz}$, DMSO-d6) for the enantiomeric pair 18; Figure S17. Electrospray ESI data for enantiomeric pair 18.

Author Contributions: Conceptualization: E.S., G.S., P.M.-d.-C., E.P., M.P., M.E.T. and C.F.; methodology: C.F., F.D., S.C., J.F.-S. and N.S.; software: F.D. and S.C.; formal analysis: F.D., S.C., E.S., G.S. and C.F.; investigation: F.D., S.C., N.S. and J.F.-S.; resources: G.S.; P.M.-d.-C., E.P. and M.P.; data curation: F.D. and S.C.; writing-original draft preparation: F.D. and C.F.; writing-review and editing: E.S., G.S., P.M.-d.-C., E.P. M.P., M.E.T. and C.F.; supervision: E.S., M.P., C.F., M.E.T. and G.S.; project administration: E.S.; funding acquisition: E.S. All authors have read and agreed to the published version of the manuscript.

Funding: This research was supported by national funds through FCT (Foundation for Science and Technology) within the scope of UIDB/04423/2020, UIDP/04423/2020 (Group of Natural Products and Medicinal Chemistry-CIIMAR), and under the project PTDC/SAU-PUB/28736/2017 (reference POCI-01-0145-FEDER-028736), co-financed by COMPETE 2020, Portugal 2020 and the European Union through the ERDF and by FCT through national funds and structured program of R\&D\&I ATLANTIDA (NORTE-01-0145-FEDER-000040), supported by NORTE2020, through ERDF; CHIRALBIO ACTIVE-PI-3RL-IINFACTS-2019 and CHIRALSINTESE-APSFCT-IINFACTS_2021.

Institutional Review Board Statement: Not applicable.

Informed Consent Statement: Not applicable.

Data Availability Statement: Not applicable. 
Acknowledgments: The acrA gene inactivated mutant Salmonella enterica serovar Typhimurium SL1344 (SE03), was provided by Jessica Blair, Institute of Microbiology and Infection, College of Medical and Dental Sciences, University of Birmingham, UK. The methicillin and ofloxacin-resistant Staphylococcus aureus 272123 clinical isolate was provided by Leonard Amaral, Institute of Hygiene and Tropical Medicine, Lisbon, Portugal. The bacteria used for the QS assay were kindly provided by Ernő Szegedi, Institute of Viticulture and Enology, National Agricultural Research Center, Badacsonytomaj, Hungary. F.D. acknowledges FCT for his grant (SFRH/BD/144681/2019). The authors thank Gisela Adriano and Gábor Tóth for the technical support.

Conflicts of Interest: The authors declare no conflict of interest.

\section{References}

1. Mahlapuu, M.; Håkansson, J.; Ringstad, L.; Björn, C. Antimicrobial peptides: An emerging category of therapeutic agents. Front. Cell Infect. Microbiol. 2016, 6, 194. [CrossRef] [PubMed]

2. Gan, B.H.; Gaynord, J.; Rowe, S.M.; Deingruber, T.; Spring, D.R. The multifaceted nature of antimicrobial peptides: Current synthetic chemistry approaches and future directions. Chem. Soc. Rev. 2021, 50, 7820-7880. [CrossRef]

3. Brogden, K.A. Antimicrobial peptides: Pore formers or metabolic inhibitors in bacteria? Nat. Rev. Microbiol. 2005, 3, 238-250. [CrossRef]

4. Kuppusamy, R.; Willcox, M.; Black, D.S.; Kumar, N. Short cationic peptidomimetic antimicrobials. Antibiotics $2019,8,44$. [CrossRef]

5. Elliott, A.G.; Huang, J.X.; Neve, S.; Zuegg, J.; Edwards, I.A.; Cain, A.K.; Boinett, C.J.; Barquist, L.; Lundberg, C.V.; Steen, J.; et al. An amphipathic peptide with antibiotic activity against multidrug-resistant Gram-negative bacteria. Nat. Commun. 2020, 11, 3184. [CrossRef]

6. Duperthuy, M. Antimicrobial peptides: Virulence and resistance modulation in gram-negative bacteria. Microorganisms 2020, 8 , 280. [CrossRef]

7. Wang, J.; Song, J.; Yang, Z.; He, S.; Yang, Y.; Feng, X.; Dou, X.; Shan, A. Antimicrobial peptides with high proteolytic resistance for combating gram-negative bacteria. J. Med. Chem. 2019, 62, 2286-2304. [CrossRef] [PubMed]

8. Malanovic, N.; Lohner, K. Antimicrobial peptides targeting gram-positive bacteria. Pharmaceuticals 2016, 9, 59. [CrossRef] [PubMed]

9. Yang, M.; Zhang, C.; Zhang, M.Z.; Zhang, S. Beta-defensin derived cationic antimicrobial peptides with potent killing activity against gram negative and gram positive bacteria. BMC Microbiol. 2018, 18, 54. [CrossRef] [PubMed]

10. Li, J.; Koh, J.-J.; Liu, S.; Lakshminarayanan, R.; Verma, C.S.; Beuerman, R.W. Membrane active antimicrobial peptides: Translating mechanistic insights to design. Front. Neurosci. 2017, 11, 73. [CrossRef]

11. Shai, Y. Mechanism of the binding, insertion and destabilization of phospholipid bilayer membranes by $\alpha$-helical antimicrobial and cell non-selective membrane-lytic peptides. Biochim. Biophys. Acta-Biomembr. 1999, 1462, 55-70. [CrossRef]

12. Omardien, S.; Brul, S.; Zaat, S.A.J. Antimicrobial activity of cationic antimicrobial peptides against gram-positives: Current progress made in understanding the mode of action and the response of bacteria. Front. Cell Dev. Biol. 2016, 4, 111. [CrossRef] [PubMed]

13. Yasir, M.; Willcox, M.D.P.; Dutta, D. Action of antimicrobial peptides against bacterial biofilms. Materials 2018, 11, 2468. [CrossRef] [PubMed]

14. Galdiero, E.; Lombardi, L.; Falanga, A.; Libralato, G.; Guida, M.; Carotenuto, R. Biofilms: Novel strategies based on antimicrobial peptides. Pharmaceutics 2019, 11, 322. [CrossRef] [PubMed]

15. Shang, D.; Han, X.; Du, W.; Kou, Z.; Jiang, F. Trp-containing antibacterial peptides impair quorum sensing and biofilm development in multidrug-resistant Pseudomonas aeruginosa and exhibit synergistic effects with antibiotics. Front. Microbiol. 2021, 12, 185. [CrossRef] [PubMed]

16. Verbeke, F.; De Craemer, S.; Debunne, N.; Janssens, Y.; Wynendaele, E.; Van de Wiele, C.; De Spiegeleer, B. Peptides as quorum sensing molecules: Measurement techniques and obtained levels in vitro and in vivo. Front. Neurosci. 2017, 11, 183. [CrossRef]

17. Gruenheid, S.; Le Moual, H. Resistance to antimicrobial peptides in Gram-negative bacteria. FEMS Microbiol. Lett. 2012, 330, 81-89. [CrossRef]

18. Assoni, L.; Milani, B.; Carvalho, M.R.; Nepomuceno, L.N.; Waz, N.T.; Guerra, M.E.S.; Converso, T.R.; Darrieux, M. Resistance mechanisms to antimicrobial peptides in gram-positive bacteria. Front. Microbiol. 2020, 11, 2362. [CrossRef]

19. Simanski, M.; Gläser, R.; Köten, B.; Meyer-Hoffert, U.; Wanner, S.; Weidenmaier, C.; Peschel, A.; Harder, J. Staphylococcus aureus subverts cutaneous defense by D-alanylation of teichoic acids. Exp. Dermatol. 2013, 22, 294-296. [CrossRef]

20. Kandaswamy, K.; Liew, T.H.; Wang, C.Y.; Huston-Warren, E.; Meyer-Hoffert, U.; Hultenby, K.; Schröder, J.M.; Caparon, M.G.; Normark, S.; Henriques-Normark, B.; et al. Focal targeting by human $\beta$-defensin 2 disrupts localized virulence factor assembly sites in Enterococcus faecalis. Proc. Natl. Acad. Sci. USA 2013, 110, 20230-20235. [CrossRef]

21. Schmidtchen, A.; Frick, I.M.; Andersson, E.; Tapper, H.; Björck, L. Proteinases of common pathogenic bacteria degrade and inactivate the antibacterial peptide LL-37. Mol. Microbiol. 2002, 46, 157-168. [CrossRef] 
22. Sieprawska-Lupa, M.; Mydel, P.; Krawczyk, K.; Wójcik, K.; Puklo, M.; Lupa, B.; Suder, P.; Silberring, J.; Reed, M.; Pohl, J.; et al. Degradation of human antimicrobial peptide LL-37 by Staphylococcus aureus-derived proteinases. Antimicrob. Agents Chemother. 2004, 48, 4673-4679. [CrossRef]

23. Llobet, E.; Tomás, J.M.; Bengoechea, J.A. Capsule polysaccharide is a bacterial decoy for antimicrobial peptides. Microbiology 2008, 154, 3877-3886. [CrossRef] [PubMed]

24. Bergholz, T.M.; Tang, S.; Wiedmann, M.; Boor, K.J. Nisin resistance of Listeria monocytogenes is increased by exposure to salt stress and is mediated via LiaR. Appl. Environ. Microbiol. 2013, 79, 5682-5688. [CrossRef] [PubMed]

25. Wu, X.; Ju, X.; Du, L.; Wang, L.; He, R.; Chen, Z. The Man-PTS subunit IIC is responsible for the sensitivity of Listeria monocytogenes to durancin GL. Food Sci. Nutr. 2020, 8, 150-161. [CrossRef]

26. Gebhard, S.; Fang, C.; Shaaly, A.; Leslie, D.J.; Weimar, M.R.; Kalamorz, F.; Carne, A.; Cook, G.M. Identification and characterization of a bacitracin resistance network in Enterococcus faecalis. Antimicrob. Agents Chemother. 2014, 58, 1425-1433. [CrossRef]

27. Draper, L.A.; Grainger, K.; Deegan, L.H.; Cotter, P.D.; Hill, C.; Ross, R.P. Cross-immunity and immune mimicry as mechanisms of resistance to the lantibiotic lacticin 3147. Mol. Microbiol. 2009, 71, 1043-1054. [CrossRef] [PubMed]

28. Koh, J.J.; Lin, S.; Aung, T.T.; Lim, F.; Zou, H.; Bai, Y.; Li, J.; Lin, H.; Pang, L.M.; Koh, W.L.; et al. Amino acid modified xanthone derivatives: Novel, highly promising membrane-active antimicrobials for multidrug-resistant Gram-positive bacterial infections. J. Med. Chem. 2015, 58, 739-752. [CrossRef] [PubMed]

29. Chen, X.; Leng, J.; Rakesh, K.P.; Darshini, N.; Shubhavathi, T.; Vivek, H.K.; Mallesha, N.; Qin, H.-L. Synthesis and molecular docking studies of xanthone attached amino acids as potential antimicrobial and anti-inflammatory agents. MedChemComm 2017, 8, 1706-1719. [CrossRef]

30. Resende, D.I.S.P.; Pereira-Terra, P.; Moreira, J.; Freitas-Silva, J.; Lemos, A.; Gales, L.; Pinto, E.; de Sousa, M.E.; da Costa, P.M.; Pinto, M.M.M. Synthesis of a small library of nature-inspired Xanthones and study of their antimicrobial activity. Molecules 2020, 25, 2405. [CrossRef] [PubMed]

31. Bessa, L.J.; Palmeira, A.; Gomes, A.S.; Vasconcelos, V.; Sousa, E.; Pinto, M.; Martins da Costa, P. Synergistic effects between thioxanthones and oxacillin against methicillin-resistant Staphylococcus aureus. Microb. Drug Resist. 2015, 21, 404-415. [CrossRef] [PubMed]

32. Durães, F.; Resende, D.I.S.P.; Palmeira, A.; Szemerédi, N.; Pinto, M.M.M.; Spengler, G.; Sousa, E. Xanthones active against multidrug resistance and virulence mechanisms of bacteria. Antibiotics 2021, 10, 600. [CrossRef] [PubMed]

33. Phyo, Y.Z.; Teixeira, J.; Gonçalves, R.; Palmeira, A.; Tiritan, M.E.; Bousbaa, H.; Pinto, M.M.M.; Fernandes, C.; Kijjoa, A. Chiral derivatives of xanthones and benzophenones: Synthesis, enantioseparation, molecular docking, and tumor cell growth inhibition studies. Chirality 2021, 33, 153-166. [CrossRef] [PubMed]

34. Carraro, M.L.; Marques, S.; Silva, A.S.; Freitas, B.; Silva, P.M.A.; Pedrosa, J.; De Marco, P.; Bousbaa, H.; Fernandes, C.; Tiritan, M.E.; et al. Synthesis of new chiral derivatives of xanthones with enantioselective effect on tumor cell growth and DNA crosslinking. ChemistrySelect 2020, 5, 10285-10291. [CrossRef]

35. Lopes, A.; Martins, E.; Silva, R.; Pinto, M.M.M.; Remião, F.; Sousa, E.; Fernandes, C. Chiral thioxanthones as modulators of P-glycoprotein: Synthesis and enantioselectivity studies. Molecules 2018, 23, 626. [CrossRef] [PubMed]

36. Fernandes, C.; Palmeira, A.; Ramos, I.I.; Carneiro, C.; Afonso, C.; Tiritan, M.E.; Cidade, H.; Pinto, P.; Saraiva, M.; Reis, S.; et al. Chiral derivatives of xanthones: Investigation of the effect of enantioselectivity on inhibition of cyclooxygenases (COX-1 and COX-2) and binding interaction with human serum albumin. Pharmaceuticals 2017, 10, 50. [CrossRef]

37. Fernandes, C.; Masawang, K.; Tiritan, M.E.; Sousa, E.; de Lima, V.; Afonso, C.; Bousbaa, H.; Sudprasert, W.; Pedro, M.; Pinto, M.M. New chiral derivatives of xanthones: Synthesis and investigation of enantioselectivity as inhibitors of growth of human tumor cell lines. Bioorg. Med. Chem. 2014, 22, 1049-1062. [CrossRef]

38. Fernandes, C.; Carraro, M.L.; Ribeiro, J.; Araújo, J.; Tiritan, M.E.; Pinto, M.M.M. Synthetic chiral derivatives of xanthones: Biological activities and enantioselectivity studies. Molecules 2019, 24, 791. [CrossRef]

39. Araújo, J.; Fernandes, C.; Pinto, M.; Tiritan, M.E. Chiral derivatives of xanthones with antimicrobial activity. Molecules 2019, 24, 314. [CrossRef]

40. Rukachaisirikul, V.; Phainuphong, P.; Sukpondma, Y.; Phongpaichit, S.; Taylor, W.C. Antibacterial caged-tetraprenylated xanthones from the stem bark of Garcinia scortechinii. Planta Med. 2005, 71, 165-170. [CrossRef]

41. Sousa, E.; Paiva, A.; Nazareth, N.; Gales, L.; Damas, A.M.; Nascimento, M.S.J.; Pinto, M. Bromoalkoxyxanthones as promising antitumor agents: Synthesis, crystal structure and effect on human tumor cell lines. Eur. J. Med. Chem. 2009, 44, 3830-3835. [CrossRef]

42. Valeur, E.; Bradley, M. Amide bond formation: Beyond the myth of coupling reagents. Chem. Soc. Rev. 2009, 38, 606-631. [CrossRef] [PubMed]

43. Balalaie, S.; Mahdidoust, M.; Eshaghi-Najafabadi, R. 2-(1H-Benzotriazole-1-yl)-1,1,3,3-tetramethyluronium tetrafluoro borate (TBTU) as an efficient coupling reagent for the esterification of carboxylic acids with alcohols and phenols at room temperature. Chin. J. Chem. 2008, 26, 1141-1144. [CrossRef]

44. Fernandes, C.; Oliveira, L.; Tiritan, M.E.; Leitao, L.; Pozzi, A.; Noronha-Matos, J.B.; Correia-de-Sá, P.; Pinto, M.M. Synthesis of new chiral xanthone derivatives acting as nerve conduction blockers in the rat sciatic nerve. Eur. J. Med. Chem. 2012, 55, 1-11. [CrossRef] 
45. Carraro, M.L.; Palmeira, A.; Tiritan, M.E.; Fernandes, C.; Pinto, M.M.M. Resolution, determination of enantiomeric purity and chiral recognition mechanism of new xanthone derivatives on $(S, S)$-whelk-O1 stationary phase. Chirality 2017, 29, 247-256. [CrossRef] [PubMed]

46. Fernandes, C.; Palmeira, A.; Santos, A.; Tiritan, M.E.; Afonso, C.; Pinto, M.M. Enantioresolution of chiral derivatives of xanthones on $(S, S)$-Whelk-O1 and L-phenylglycine stationary phases and chiral recognition mechanism by docking approach for $(S, S)$ Whelk-O1. Chirality 2013, 25, 89-100. [CrossRef]

47. Shi, X.; Chen, M.; Yu, Z.; Bell, J.M.; Wang, H.; Forrester, I.; Villarreal, H.; Jakana, J.; Du, D.; Luisi, B.F.; et al. In situ structure and assembly of the multidrug efflux pump AcrAB-TolC. Nat. Commun. 2019, 10, 2635. [CrossRef] [PubMed]

48. Aron, Z.; Opperman, T.J. The hydrophobic trap-The Achilles heel of RND efflux pumps. Res. Microbiol. 2018, 169, 393-400. [CrossRef]

49. Zárate, S.G.; Morales, P.; Świderek, K.; Bolanos-Garcia, V.M.; Bastida, A. A molecular modeling approach to identify novel inhibitors of the major facilitator superfamily of efflux pump transporters. Antibiotics 2019, 8, 25. [CrossRef]

50. Durães, F.; Pinto, M.; Sousa, E. Medicinal chemistry updates on bacterial efflux pump modulators. Curr. Med. Chem. 2018, 25, 6030-6069. [CrossRef]

51. Bessa, L.J.; Barbosa-Vasconcelos, A.; Mendes, A.; Vaz-Pires, P.; Martins da Costa, P. High prevalence of multidrug-resistant Escherichia coli and Enterococcus spp. in river water, upstream and downstream of a wastewater treatment plant. J. Water Health 2014, 12, 426-435. [CrossRef]

52. Viveiros, M.; Rodrigues, L.; Martins, M.; Couto, I.; Spengler, G.; Martins, A.; Amaral, L. Evaluation of efflux activity of bacteria by a semi-automated fluorometric system. In Antibiotic Resistance Protocols, 2nd ed.; Gillespie, S.H., McHugh, T.D., Eds.; Humana Press: Totowa, NJ, USA, 2010; pp. 159-172.

53. Durães, F.; Palmeira, A.; Cruz, B.; Freitas-Silva, J.; Szemerédi, N.; Gales, L.; da Costa, P.M.; Remião, F.; Silva, R.; Pinto, M.; et al. Antimicrobial activity of a library of thioxanthones and their potential as efflux pump inhibitors. Pharmaceuticals 2021, 14, 572. [CrossRef] [PubMed]

54. Eicher, T.; Cha, H.-J.; Seeger, M.A.; Brandstätter, L.; El-Delik, J.; Bohnert, J.A.; Kern, W.V.; Verrey, F.; Grütter, M.G.; Diederichs, K.; et al. Transport of drugs by the multidrug transporter AcrB involves an access and a deep binding pocket that are separated by a switch-loop. Proc. Natl. Acad. Sci. USA 2012, 109, 5687. [CrossRef] [PubMed]

55. Lekshmi, M.; Parvathi, A.; Kumar, S.; Varela, M.F. Efflux pump-mediated quorum sensing: New avenues for modulation of antimicrobial resistance and bacterial virulence. In Biotechnological Applications of Quorum Sensing Inhibitors; Kalia, V.C., Ed.; Springer: Singapore, 2018; pp. 127-142.

56. Kvist, M.; Hancock, V.; Klemm, P. Inactivation of efflux pumps abolishes bacterial biofilm formation. Appl. Environ. Microbiol. 2008, 74, 7376-7382. [CrossRef]

57. Alav, I.; Sutton, J.M.; Rahman, K.M. Role of bacterial efflux pumps in biofilm formation. J. Antimicrob. Chemother. 2018, 73, 2003-2020. [CrossRef] [PubMed]

58. Parai, D.; Banerjee, M.; Dey, P.; Mukherjee, S.K. Reserpine attenuates biofilm formation and virulence of Staphylococcus aureus. Microb. Pathog. 2020, 138, 103790. [CrossRef]

59. Gajdács, M.; Spengler, G. The role of drug repurposing in the development of novel antimicrobial drugs: Non-antibiotic pharmacological agents as quorum sensing-inhibitors. Antibiotics 2019, 8, 270. [CrossRef]

60. Gajdács, M.; Spengler, G. Standard operating procedure (SOP) for disk diffusion-based quorum sensing inhibition assays. Acta Pharm. Hung. 2020, 89, 117-125. [CrossRef]

61. Benomar, S.; Evans, K.C.; Unckless, R.L.; Chandler, J.R. Efflux pumps in Chromobacterium species increase antibiotic resistance and promote survival in a coculture competition model. Appl. Environ. Microbiol. 2019, 85, e00908-19. [CrossRef]

62. Phyo, Y.Z.; Teixeira, J.; Tiritan, M.E.; Cravo, S.; Palmeira, A.; Gales, L.; Silva, A.M.S.; Pinto, M.M.M.; Kijjoa, A.; Fernandes, C. New chiral stationary phases for liquid chromatography based on small molecules: Development, enantioresolution evaluation and chiral recognition mechanisms. Chirality 2020, 32, 81-97. [CrossRef]

63. Magano, J.; Chen, M.H.; Clark, J.D.; Nussbaumer, T. 2-(Diethylamino)ethanethiol, a new reagent for the odorless deprotection of aromatic methyl ethers. J. Org. Chem. 2006, 71, 7103-7105. [CrossRef] [PubMed]

64. Tiritan, M.E.; Fernandes, C.; Maia, A.S.; Pinto, M.; Cass, Q.B. Enantiomeric ratios: Why so many notations? J. Chromatogr. A 2018, 1569, 1-7. [CrossRef]

65. Mikolosko, J.; Bobyk, K.; Zgurskaya, H.I.; Ghosh, P. Conformational flexibility in the multidrug efflux system protein AcrA. Structure 2006, 14, 577-587. [CrossRef] [PubMed]

66. Koronakis, V.; Sharff, A.; Koronakis, E.; Luisi, B.; Hughes, C. Crystal structure of the bacterial membrane protein TolC central to multidrug efflux and protein export. Nature 2000, 405, 914-919. [CrossRef]

67. Sussman, J.L.; Lin, D.; Jiang, J.; Manning, N.O.; Prilusky, J.; Ritter, O.; Abola, E.E. Protein Data Bank (PDB): Database of three-dimensional structural information of biological macromolecules. Acta Crystallogr. D Biol. Crystallogr. 1998, 54, 1078-1084. [CrossRef] [PubMed]

68. Trott, O.; Olson, A.J. AutoDock vina: Improving the speed and accuracy of docking with a new scoring function, efficient optimization, and multithreading. J. Comput. Chem. 2010, 31, 455-461. [CrossRef] [PubMed] 
69. Waterhouse, A.; Bertoni, M.; Bienert, S.; Studer, G.; Tauriello, G.; Gumienny, R.; Heer, F.T.; de Beer, T.A.P.; Rempfer, C.; Bordoli, L.; et al. SWISS-MODEL: Homology modelling of protein structures and complexes. Nucleic Acids Res. 2018, 46, W296-W303. [CrossRef]

70. The UniProt Consortium. UniProt: The universal protein knowledgebase. Nucleic Acids Res. 2017, 45, D15-D169. [CrossRef]

71. Seeliger, D.; de Groot, B.L. Ligand docking and binding site analysis with PyMOL and Autodock/Vina. J. Comput.-Aided Mol. Des. 2010, 24, 417-422. [CrossRef]

72. CLSI. Methods for Dilution Antimicrobial Susceptibility Tests for Bacteria that Grow Aerobically, 11th ed.; Clinical and Laboratory Standards Institute: Wayne, PA, USA, 2018.

73. CLSI. Clinical and Laboratory Standards Institute: Reference Method for Broth Dilution Antifungal Susceptibility Testing of Yeasts; Approved standard-CLSI document M27-A3; Clinical and Laboratory Standards Institute: Wayne, PA, USA, 2008 ; Volume 28.

74. CLSI. Reference Method for Broth Dilution Antifungal Susceptibility Testing of Filamentous Fungi; Approved Standard-Second Edition. CLSI document M38-A2; Clinical and Laboratory Standards Institute: Wayne, PA, USA, 2008.

75. Nové, M.; Kincses, A.; Szalontai, B.; Rácz, B.; Blair, J.M.A.; González-Prádena, A.; Benito-Lama, M.; Domínguez-Álvarez, E.; Spengler, G. Biofilm eradication by symmetrical selenoesters for food-borne pathogens. Microorganisms 2020, 8, 566. [CrossRef] 